\title{
El principio de no interferencia judicial sobre los arbitrajes: Comentarios al artículo 3 de la Ley de Arbitraje peruana $\left.{ }^{*}\right)$
}

\author{
The principle of judicial non interference in arbitrations: Comments on Article \\ 3 of the Peruvian Arbitration Law
}

\author{
Raffo Velásquez Meléndez(*) \\ Baxel Consultores (Lima, Perú) \\ Juan Chang Tokushima ${ }^{(*+*)}$ \\ Baxel Consultores (Lima, Perú)
}

\begin{abstract}
Resumen: Las virtudes del arbitraje dependen del principio de no interferencia judicial en su trámite y de un régimen limitado de control judicial posterior de los arbitrajes. Sin embargo, existe mucha confusión y complejidad en la articulación de las distintas vías procesales de control aplicables a los arbitrajes, la oportunidad de su activación y sus alcances. El artículo 3 de la Ley de Arbitraje consagra el principio de no interferencia judicial, pero necesita ser comprendido dentro de todo el entramado de defensas procesales existentes. Para esos propósitos, la historia de la jurisprudencia nacional y comparada juega un papel sumamente relevante.
\end{abstract}

Palabras clave: Arbitraje - Laudos - Amparo - Anulación de laudos - Terceros - Poder Judicial - Jurisprudencia constitucional - Jurisprudencia comparada - Perú

\begin{abstract}
The virtues of arbitration depend on the principle of judicial non-interference in its proceedings and on a limited regime of subsequent judicial control of arbitrations. However, there is a lot of confusion about the articulation of the different procedural control channels applicable to arbitrations, the timing of their activation and their scope. Article 3 of the Arbitration Act establishes the principle of judicial non-interference, but it needs to be understood within the entire framework of existing procedural defenses. For these purposes, the history of national and comparative jurisprudence plays an extremely relevant role.
\end{abstract}

Keywords: Arbitration - Awards - Annulment of awards - Third parties - Judicial Power - Constitutional jurisprudence - Comparative jurisprudence - Peru

$\left(^{*}\right) \quad$ Nota del editor: este artículo fue recibido el 12 de noviembre de 2020, y su publicación fue aprobada el 7 de abril de 2021.

$\left({ }^{* *}\right)$ Magíster en Argumentación Jurídica por la Universidad de Alicante y la Università degli studi di Palermo; Posgrado en Arbitraje Comercial Internacional por la Universidad Complutense de Madrid. Abogado por la Universidad Nacional Mayor de San Marcos. Socio de Baxel Consultores. ORCID: https://orcid.org/0000-0002-1208-5959. Correo electrónico rvelasquez@baxel.pe.

${ }^{(* * *}$ Magíster en Economía, Regulación y Competencia de los Servicios Públicos, por la Universidad de Barcelona. Abogado por la Pontificia Universidad Católica del Perú. Socio de Baxel Consultores. ORCID: https://orcid.org/0000-0002-2655-6897. Correo electrónico: jchang@baxel.pe. 


\section{A modo de introducción}

El acuerdo libre entre dos o más partes para someter sus eventuales controversias a un arbitraje tiene como propósito evidente evitar la vía judicial y acudir a una vía que los contratantes estiman más adecuadas por distintas razones (especialidad, rapidez, flexibilidad, etc.).

Esto se puede ver truncado si se permite que, antes, durante o después de las controversias arbitrales, el Poder Judicial tenga carta abierta para impedir la eficacia del acuerdo de las partes de arbitrar sus diferencias. Eso podría darse, por ejemplo, si se facilita que aquéllas eludan sus convenios arbitrales y tengan libre acceso al Poder Judicial para discutir las mismas materias que pactaron; si se permite que los jueces interrumpan o perturben el trámite de un arbitraje que está en curso; si se niega eficacia a un laudo arbitral, lo que podría darse mediante su no reconocimiento judicial (exequatur), la falta de colaboración de los jueces para su ejecución; o la amplitud y apertura de causales para invalidar laudos arbitrales.

El principio de no interferencia recoge una serie de reglas que tienen como norte garantizar la autonomía privada, en específico, evitar medidas judiciales que perturben la eficacia de los acuerdos arbitrales y de los eventuales procesos arbitrales y laudos que tales convenios pudieran generar.

Veremos que eso no significa que los arbitrajes tienen una relación totalmente con el ámbito judicial, sino que el principio en cuestión exige una interacción limitada y excepcional entre las vías arbitrales y judiciales de tutela de derechos.

De hecho, existe cierta historia normativa y jurisprudencial que da forma a los actuales perfiles del principio de no interferencia judicial sobre los arbitrajes, lo que otorga ciertas peculiaridades a nuestro sistema de control e intervención judicial sobre estos. A pesar de que estos antecedentes sirven para explicar sus alcances, existe aún mucha confusión, dudas y nuevos cambios, que hacen difícil la aprehensión del fundamento y de los límites necesarios que subyacen en este tópico.

Si bien buscaremos comentar los alcances del artículo 3 de la Ley de Arbitraje (en adelante, "LA")(1) que recoge las bases del principio de no interferencia judicial, veremos que la explicación de aquellos fundamentos jurisprudenciales y prácticos es mucho más enriquecedora que el simple comentario exegético del texto legal.

\section{Fundamento del principio de no interferencia}

La "inarbitrabilidad" en su dimensión objetiva hace referencia a las materias que no pueden ser atendidas por la justicia arbitral, debido a la decisión estatal de excluirlas o reservarlas de modo exclusivo para los Jueces, invocando motivos de orden público, relevancia social, económica o cualquier otra razón de política pública.

En contrapartida, la decisión libre de las partes de someter a arbitrajes asuntos que sí permite la ley, debe estar acompañada de la necesaria garantía para no interferir la eficacia de tal decisión. No hay duda de que quien plantea una pretensión estará interesado en un proceso arbitral rápido, que no sea interrumpido o perturbado con alguna intervención judicial, interés con el que podría comulgar o no el demandado u otros supuestos afectados, según las expectativas que tuvieran sobre la futura decisión arbitral por lo que, de ser el caso, podrían tener mayor interés en acudir a la vía judicial.

La revisión de los principios que enumera el art. 3 de la LA indica un fundamento común: la protección de arbitraje es una consecuencia del ejercicio del derecho fundamental a la libertad de contratación y de la autonomía privada reconocidos en los arts. 2, num. 14 y el art. 62 de la Constitución Política. $\mathrm{O}$, de manera más profunda aún, se puede decir que en esas normas subyacen el principio general de libertad del art. 2, num. 14, lit. a, de la Constitución que consagra que mientras no exista mandato o prohibición en la ley, los particulares tienen libertad de actuación,

(1) Artículo 3 LA. Principios y derechos de la función arbitral.

1. En los asuntos que se rijan por este Decreto Legislativo no intervendrá la autoridad judicial, salvo en los casos en que esta norma así lo disponga.

2. El tribunal arbitral tiene plena independencia y no está sometido a orden, disposición o autoridad que menoscabe sus atribuciones.

3. El tribunal arbitral tiene plenas atribuciones para iniciar y continuar con el trámite de las actuaciones arbitrales, decidir acerca de su propia competencia y dictar el laudo.

4. Ninguna actuación ni mandato fuera de las actuaciones arbitrales podrá dejar sin efecto las decisiones del tribunal arbitral, a excepción del control judicial posterior mediante el recurso de anulación del laudo contemplado en este Decreto Legislativo. Cualquier intervención judicial distinta, dirigida a ejercer un control de las funciones de los árbitros o a interferir en las actuaciones arbitrales antes del laudo, está sujeta a responsabilidad. 
entre otros, libertad para solucionar sus controversias por la vía arbitral. Su esfera de libertad se presume ilimitada, de modo que solo puede limitarse si existe mandato legal| ${ }^{(2)}$.

El fundamento anterior, sin embargo, debe ser complementado con los criterios del Tribunal Europeo de Derechos Humanos (TEDH), que ha tenido oportunidad de señalar que la protección contra las interferencias del Estado sobre los arbitrajes constituye una exigencia del derecho a la tutela jurisdiccional efectiva ${ }^{(3)}$. Este criterio tiene cabida en nuestro país que reconoce cualidad jurisdiccional a los arbitrajes y, en esa medida, como un instituto con suficiente potencia como para exigir la aplicación del artículo 139, núm. 2, Constitución que dispone: "Ninguna autoridad puede avocarse a causas pendientes ante el órgano jurisdiccional ni interferir en el ejercicio de sus funciones".

Ese acuerdo libre y constitucional para excluir al Poder Judicial y para discutir sus controversias en un arbitraje, genera como lógica consecuencia el principio de no interferencia judicial en los procedimientos arbitrales en trámite. Como señala Gary Born (2009, pp. 1028-1032), las órdenes judiciales que interfieren procesos arbitrales en curso contradirían directamente los objetivos de las partes al acordar un arbitraje: frustraría sus objetivos de que sus diferencias sean atendidas en un procedimiento fijados por ellos (flexible), por un Tribunal elegido por ellos, dentro de plazos acordados y con opciones limitadísimas de revisión del fallo(4)

\section{El principio de no interferencia en ciertos arbitrajes legales}

\subsection{Los arbitrajes que nacen de la voluntad de la ley}

El principio de no interferencia no tiene el mismo alcance en los arbitrajes impuestos por ley, donde no hay un acuerdo libre entre las partes para arbitrar la controversia. En tales casos no puede decirse que las partes acudieron a la vía arbitral para solucionar sus diferencias libres de las injerencias del Estado.

Por ejemplo, en los arbitrajes laborales potestativos, el art. 61 TUO de la Ley de Relaciones Colectivas de Trabajo ("LRC") prevé que: "Si no se hubiese llegado a un acuerdo en negociación directa o en conciliación, de haberla solicitado los trabajadores, podrán las partes someter el diferendo a arbitraje". El Reglamento de la LRC (art. 61-A) precisa que empleador o trabajadores pueden solicitar el inicio de arbitraje, al que deberá la contraparte deberá someterse, sin posibilidades de objetar su uso. Es decir, aunque no hayan prestado su consentimiento para la vía arbitral, empleador o trabajador no podrán "huir" de la fuerza de la ley que los somete a un arbitraje solicitado por su contraparte.

Se dice que este tipo de arbitraje es potestativo porque se activa ante el ejercicio de una potestad que concede la ley a cada parte para iniciar un arbitraje, sin que exista cláusula arbitral acordada. Sobre todo, se usa esa denominación para diferenciarlo del arbitraje laboral obligatorio, en donde ninguna de las partes tiene tal potestad, sino que es un tercero, el Estado, quien impone solucionar las diferencias en la vía arbitral, lo que, de acuerdo con el Comité de Libertad Sindical de la OIT, tiene serios indicios de inconstitucionalidad(5). Por menos, el TEDH consideró ilegítima la imposición de un

(2) Lo anterior es conocido como el principio de distribución de Carl Schmitt quien señala que "la esfera de libertad del individuo se supone como un dato anterior al Estado, quedando la libertad del individuo ilimitada en principio, mientras que la facultad del Estado para invadirla es limitada en principio". Es decir, mientras la actuación de los particulares se presume libre y solo puede ser objeto de los límites o prohibiciones expresas que fije la ley, la actuación estatal se presume limitada pues solo puede ejercerse en los asuntos que la ley habilite y no cabe fuera de esos márgenes. No se trata de una mera elucubración teórica, sino de un principio reconocido en la jurisprudencia del Tribunal Constitucional (“TC”). Cfr. STC 0009 y 0010-2007-Al (acumulados), fd. 9.

(3) Cfr. Caso Stran Greek Refineries y otro contra Grecia, sentencia del 9 de diciembre de 1994, (párr. 47-50). El caso se vinculaba a un arbitraje entre una empresa y el estado griego que favoreció al primero. Sin embargo, ante la revisión judicial del arbitraje por supuesta nulidad del convenio arbitral, el Parlamento dictó una ley que ratificaba dicha nulidad, asunto que el Tribunal Europeo consideró como una interferencia ilegítima lesiva del debido proceso, de la expectativa de llevar adelante el arbitraje sin interferencias.

(4) Cabe anotar que, Born indica que en todos los arbitrajes se pactan en procura de soluciones ágiles, eficientes y expertas. Aunque agrega que, los arbitrajes internacionales tienen la particularidad de que, además, buscan garantizar la neutralidad procesal, esto es, evitar que el Poder Judicial favorezca a las partes que le son connacionales. Sea uno u ambos fines, concluye, los objetivos de los arbitrajes se facilitan con un régimen de no intervención judicial mientras dure su trámite y con alcances limitados del posterior poder de revisión judicial de laudos y de otras decisiones arbitrales (Born, 2009, pp. 1001-1004).

(5) El art. $68 \mathrm{LRC}$ dispone que cuando se prolongue excesivamente una huelga que comprometa gravemente a una empresa, al sector productivo, derive en actos de violencia, o asuma características graves por su magnitud o consecuencias, el Ministerio de Trabajo ("Mintra") promoverá "otras formas de solución pacífica del conflicto" y de fracasar ésta, "resolverá en forma definitiva". Aunque el 
arbitraje por los accionistas mayoritarios de una empresa al minoritario. EI TEDH consideró que el Estado había vulnerado el debido proceso al no invalidar la imposición de un arbitraje no consentido por el reclamante(6).

En todo caso, en los arbitrajes que no nacen del sometimiento voluntario de las partes, las limitaciones a la intervención judicial sobre los arbitrajes provendrán del mandato legal de arbitrar y no del acuerdo entre las partes. Por lo que, estimamos que en esos supuestos sí serán posibles ciertas intervenciones judiciales de decisiones arbitrales previas al laudo, cuando agravien derechos o valores fundamentales, o cuando un mandato constitucional se superponga al mandato legislativo de arbitrar, tal como lo permiten los arts. 51 y 138 de la Constitución.

\subsection{Los arbitrajes que nacen por la voluntad de las partes y de la ley}

Distinto es el caso previsto en los arts. 32.3 y 45.1 de la Ley de Contrataciones Estatales ("LCE") y en el art. 56 de la Ley de Promoción de la Inversión mediante Asociación PúblicoPrivada ("Ley APPs") que prevé que los contratos suscritos bajo sus regímenes deben contener cláusulas de solución de las controversias entre contratista y la entidad estatal, lo que podrá realizarse mediante arbitraje. Ahora bien, en los procesos de selección o de promoción de la inversión, respectivamente, se incluye dentro de las bases al modelo de contrato que será suscrito (y que incluye la cláusula arbitral), de modo que quien participe y logre ganar la buena pro o el proyecto, lo hará porque desde un inicio prestó su consentimiento al acuerdo arbitral. Por tanto, en estos casos sí existe un acuerdo entre ambas partes de someter sus controversias a la vía arbitral y, por ende, si rige con plenitud el principio de no interferencia.

No obstante, el hecho que el convenio arbitral sea voluntario, no elimina varias críticas que existen sobre aquellos regímenes de arbitrajes contra el Estado. Al comentar el artículo 4 LA veremos que el Estado ha dictado una regulación especial que resulta bastante beneficiosa para cuando el Estado es parte de un arbitraje y perjudica a su contraparte, lo que es fuente de varias arbitrariedades y problemas pendientes de ser resueltos.

Otro caso similar son los arbitrajes vinculados a las expropiaciones (en donde se discute el monto del justiprecio, la duplicidad de partidas o pedidos de expropiación total) bajo cuyo régimen, el expropiado podrá solicitar el inicio del arbitraje.
Pero si la entidad se opone a ello (manifiesta su negativa expresa), solo podrá acudirse a la vía judicial (art. 35 del TUO del Decreto Legislativo 1192). Es decir, para el trámite de estos arbitrajes, también se necesita que concurra la voluntad de las dos partes.

En todo caso, si se trata de arbitrajes en donde media el libre consentimiento, el fundamento del principio de no interferencia estará en la autonomía privada, y en los arbitrajes forzosos o potestativos, el fundamento de aquel principio estará en la ley que impone el arbitraje como forma de solución de conflictos.

\section{Las consecuencias del principio de no interferencia judicial}

Una vez aclarado el fundamento del principio en cuestión, corresponde evaluar los mandatos que pueden derivarse del mismo. En la parte introductoria ya hicimos referencia que el principio en cuestión genera efectos antes, durante y después de los arbitrajes, lo que requiere ciertas precisiones adicionales.

Por ejemplo, el art. II, num. 3 de la Convención de New York sobre reconocimiento y ejecución de laudos extranjeros dispone que si una de las partes pretende eludir la eficacia de un convenio arbitral, los tribunales de los Estados deberán remitir a las partes a la vía arbitral, a pedido de una de ellas. Al respecto, Born (2009, pp. 1026-1027) entiende que esta norma impide que el principio de no injerencia judicial en los arbitrajes internacionales quede en manos de la legislación nacional, pues prohíbe al Poder Judicial hacer algo distinto al reenvío de las partes a un arbitraje.

La posibilidad de invalidar la continuación de la vía judicial para reclamar un asunto sobre el cual existe convenio arbitral es, sin duda, una manifestación del principio de no

texto no prevé la vía arbitral como forma de solución obligatoria, la práctica ha llevado al Mintra a imponer la vía arbitral en ciertos casos de alta relevancia social como una huelga minera que afectaba las exportaciones de minerales y la economía del país. Sin embargo, el Comité de Libertad Sindical de la OIT ha precisado que el arbitraje solo puede ser válido cuando lo solicitan las partes, por lo que requirió que se modifique el art. 68 LRC, pues permite una interpretación demasiado amplia del Gobierno que, en todo caso, solo debería poder aplicar esa norma cuando se trate de huelgas vinculadas a la función pública, servicios esenciales o casos de crisis nacional aguda. Cfr. Informe 302 (párrafos 512-513).

(6) Véase Caso Pavel Suda contra República Checa, sentencia del 28 de octubre de 2010, párr. 52-55. 
injerencia judicial. Sin embargo, según la Convención de New York, la posibilidad de seguir o no en la vía judicial queda siempre en manos de los privados al disponer que el Poder Judicial "remitirá a las partes al arbitraje, a instancia de una de ellas", sin que se recoja la prohibición absoluta de que los jueces conozca de esos casos, tal como sugiere Born.

Por ese motivo, los arts. 16 y 18 LA establecen que si una de las partes decide eludir el convenio arbitral y trasladar la causa a la vía judicial y la otra parte no objeta ese proceder, sino que lo consiente al contestar la demanda y no deducir la excepción de convenio arbitral, se entenderá que, para esa controversia específica, las partes han acordado acudir a la sede judicial. Eso, sin embargo, no significará una renuncia total a cualquier otra controversia distinta o posterior entre tales partes, pues al demandar y contestar la demanda en la vía judicial, las partes solo han expresado su renuncia de arbitraje respecto de ese asunto y nada más.

Desde luego que, también se encuentra la opción contraria, esto es, que la parte demandada de modo indebido en la vía judicial deduzca la excepción de convenio arbitral. En tal caso, los jueces deben desestimar la demanda judicial y condenar al pago de costas y costos a quien indebidamente fue demandado en esa vía. De hecho, pueden darse casos de partes rebeldes al arbitraje que inicien o amenacen con distintas acciones en la vía judicial. En el derecho comparado se han previsto algunas opciones de defensa para esos supuestos conocidas como medidas cautelares anti-procesos (traducción de anti-suit injunctions). Se trata de un asunto discutible, pues se trata de un mandato cautelar que interferiría con el conocimiento del caso por parte de un juez (y que bien podría declararse incompetente por existir un convenio arbitral), Reggiardo y Cuba (2020, pp. 248-250) estiman que existen razones para admitir el uso de ese instrumento en nuestro sistema jurídico, a fin de garantizar la independencia de la justicia arbitral.

El principio de no injerencia también se manifiesta luego de concluido el arbitraje: al momento de ejecutar el laudo y/o al momento de revisar la validez del laudo. Para la eficacia del laudo arbitral, el legislador establece que se debe iniciar un proceso de ejecución (art. 688, inc. 2, del Código Procesal Civil). La característica de esta vía judicial es que no deja opción a que el demandado ejerza defensas que abran la posibilidad de que el Juez revise el fondo de lo decidido, sino que solo puede plantear defensas formales (inexigibilidad o iliquidez del laudo, su falsedad, o el cumplimiento del laudo, ex art. 690-D del Código Procesal Civil). La injerencia judicial en el contenido del laudo es mínima.

De manera similar, para revisar la validez del laudo, vía recurso de anulación, el legislador establece tres reglas esenciales que son manifestaciones del principio de mínima injerencia: (i) toda revisión judicial es posterior, es decir, luego de que se dicta el laudo (art. 62, inc. 1, LA), lo que impide interrupciones o revisiones judiciales de las decisiones arbitrales mientras aún se tramita el arbitraje; (ii) no cabe revisión del fondo de lo decidido (art. 62, inc. 2, LA); (iii) solo cabe revisión por las causales formales y específicas establecidas (art. 63, LA).

Como se aprecia, el principio de no interferencia judicial sobre los arbitrajes genera un campo limitadísimo de interacción entre arbitrajes y vías judiciales. Ese campo busca asegurar que el Poder Judicial no interrumpa ni perturbe el trámite del procedimiento arbitral y, más aún, que no pueda revisar, ni sustituir, el fondo de lo decidido en el arbitraje.

Con esto aclarado, en lo sucesivo nos enfocaremos en averiguar cómo es que opera el principio de mínima injerencia judicial en su versión de control posterior de los arbitrajes. Para fines explicativos hemos hecho mención solo al camino judicial de la anulación de laudo. Sin embargo, la situación es más compleja que eso, pues también incluye la vía de los procesos de amparo. La interacción entre uno y otro camino judicial, los espacios por donde transitan uno y otro, han sido construidos por el derrotero jurisprudencial que veremos a continuación.

\section{La tragedia peruana de la no interferencia judicial en los arbitrajes}

Como todo principio, el de no interferencia no es absoluto, sino que convive en constante tensión con el principio de justicia. Mientras el primero busca asegurar la rápida obtención de la decisión de arbitraje y su pronta eficacia, el segundo busca evitar decisiones perversas que rompan las mínimas expectativas de justicia. Sin rapidez y eficacia de los arbitrajes como mecanismo de solución de controversias, la fiabilidad de las transacciones que optan por esa vía puede verse perjudicada. Sin embargo, ese propósito no debe llevarnos a olvidar que se necesita cierto control que garantice una mínima justicia procesal en el trámite de la controversia (garantizada por el debido proceso) y/o que el arbitraje efectivamente respete los alcances de convenio arbitral lícitamente pactados que le sirvieron de 
fundamento, criterios que inspiran las causales taxativas de anulación de laudos.

La experiencia de la legislación arbitral del Bélgica nos advierte sobre la necesidad de no olvidar esta convivencia de principios. Para incentivar y dar mayores garantías a los arbitrajes internacionales, en 1985 se estableció un régimen que impedía la posibilidad de revisión por parte de los jueces. Sin embargo, las empresas se mostraron temerosas de la existencia de laudos irrevisables, por lo que ese régimen no les fue muy atractivo. Por eso, en 1998 el legislador belga tuvo que volver a un régimen de revisión judicial limitado. Y es que, como concluye Park (2012, p. 600): "Aunque la supervisión judicial del arbitraje no será completamente infalible, el sentido común sugiere que la mala conducta es menos probable cuando el comportamiento está sujeto al escrutinio público y a la sanción".

En nuestro país, la experiencia sobre la revisión judicial del arbitraje ha sido bastante más traumática, llena de giros, idas y vueltas, en los criterios aplicables. Podría decirse que el principio de no intervención fue aprendido a partir de la técnica del ensayo y error, lo que ha dado perfiles particulares a nuestro sistema jurídico.

Al amparo de la anterior Ley de Arbitraje - Ley 26572, se dictaron varias medidas cautelares judiciales que trabaron la instalación de tribunales arbitrales, el trámite de esos procesos privados, la actuación de pruebas o la ejecución de otras cautelares arbitrales o incluso el laudo mismo. Hasta hubo procesos penales contra los árbitros y otras estrategias prolíficas para desvincularse del convenio arbitral.

El caso más conocido fue el de Minera Sulliden vs. Grupo Algamarca. Exploraciones Algamarca (una de las demandadas) trabó judicialmente aquel arbitraje y para ello: (i) obtuvo una cautelar en un amparo que suspendió el arbitraje, alegando que el contrato y el convenio arbitral no le eran vinculantes; y, (ii) denunció penalmente al árbitro y profesor Fernando Cantuarias, a quien acusaron de falsedad genérica y fraude procesal. Eso motivó que aquel árbitro interpusiera un habeas corpus contra el proceso penal que se le había iniciado. El amparo y el habeas corpus llegaron hasta el TC que trató de enmendar el laberinto judicial y arbitral generado y, aunque ocasionó nuevas dudas, también aclaró que el arbitraje tenía autonomía e independencia jurisdiccional y, por lo tanto, que era inválido cualquier medida judicial dirigida a interferir con su trámite ${ }^{(7)}$.
El hábeas corpus de Fernando Cantuarias sirvió para que el TC fije como precedente vinculante que las decisiones arbitrales solo puedan impugnarse en amparo luego de agotarse la "vía previa", es decir, luego del laudo y del recurso de anulación, criterio que también aplicó al resolver el amparo de Exploraciones Algamarca.

Aunque la finalidad del TC fue evitar la interferencia judicial sobre arbitrajes en trámite, pronto los litigantes aprovecharon la calificación de "vía previa" que había dado el TC al proceso arbitral y al proceso de anulación. En efecto, se empezaron a invocar las distintas causales que exceptúan agotar la vía previa (art. 46 del Código Procesal Constitucional - "CPconst") para activar la vía de amparo contra arbitrajes que aún estaban en trámite.

Pero el caso Fernando Cantuarias trajo otras confusiones y errores más. Estableció algo contrario a las creencias de este profesor de derecho arbitral: que los arbitrajes no adquieren su poder de la autonomía de las partes ${ }^{(8)}$, sino del reconocimiento constitucional del arbitraje como "jurisdicción" (art. 139, num. 1, Constitución). Por eso, los árbitros tendrían poder para impartir justicia y como ese poder -continua el TC-no se agota con lo previsto en el contrato, sino que deriva de la Constitución, los árbitros deben respetar las garantías fundamentales, en especial, las de la tutela jurisdiccional efectiva.

EI TC invocó la calidad de "jurisdicción" para concluir que en los arbitrajes se gobiernan por los principios de la función jurisdiccional, entre ellas, la prohibición de avocamiento de causas en trámite del artículo 139, num. 2, de la Constitución. Por tanto, según el TC, en el Perú el principio de no interferencia judicial de los arbitrajes sería una consecuencia de la garantía del debido

(7) STC 1567-2005-PA (amparo de Exploraciones Algamarca) y STC 6167-2005-PHC (habeas corpus de Fernando Cantuarias Salaverry).

(8) Por ejemplo, sobre el convenio arbitral, Cantuarias señala lo siguiente: "La actual LGA no cae en el grave error de la anterior legislación, al definir correctamente al convenio arbitral en sus artículos 9 y 98, como aquel acuerdo por el que las partes deciden someter a arbitrajes las controversias que hayan surgido o puedan surgir entre ellas respecto a una determinada relación jurídica contractual o no contractual. De esta manera, independientemente del momento en que se suscriba el acuerdo de arbitraje (antes o después de qu surja la controversia), solo existirá un contrato: el convenio arbitral. De la definición que da la LGA, se desprende los únicos dos requisitos esenciales del convenio arbitral: (i) la decisión de las partes de pactar el arbitraje; y (ii) la determinación de la relación jurídica respecto de la cual se arbitrarán los actuales o potenciales conflictos". 
proceso que corresponde a la "jurisdicción" arbitral y no una garantía de la autonomía de la voluntad y del principio general de libertad. E insiste el Tribunal: la exigencia jurisdiccional de que otros no intervengan en el fuero arbitral sustentaría también el principio kompetenz-kompetenz, entendido como garantía de independencia de un Tribunal Arbitral. Esto evidencia el tremendo desconocimiento con que el TC abordó la materia arbitral al momento de dictar el precedente en comentario.

La suma de críticas contra esos criterios de TC ameritaría un estudio aparte. Por lo pronto, solo conviene resaltar que incluso sin una norma constitucional que califique al arbitraje como "jurisdicción", los árbitros deben respetar las garantías del debido proceso, porque están recogidas en normas del orden público nacional e internacional, normas imperativas que no puede eludir ningún árbitro. El error del TC es concluir que solo considerando como "jurisdicción" al arbitraje, los árbitros están vinculados a las garantías de la función jurisdiccional o a las demás garantías fundamentales.

Como ya señalamos al comentar el art. $1 \mathrm{LA}$, la calidad de "jurisdicción" de los arbitrajes fue decretada para impregnar poder jurisdiccional (de calidad de cosa juzgada) a sus decisiones, de tal suerte que pueda justificarse por qué la eventual revisión judicial de un Laudo o de una decisión arbitral, sea una cuestión realmente excepcional.

\section{El precedente Minera María Julia menguó la interferencia judicial}

Como se sabe, nuestra LA, replica gran parte de la Ley Modelo UNCITRAL. Sin embargo, el art. 3 LA tiene elementos bastante peruanos, ya que es fruto de la experiencia antes descrita. En efecto, cuando se gestaba el texto de la actual LA ocurrían los avatares que hemos descrito, lo que motivó esta norma que consagra distintas variables que aseguran el principio de no interferencia judicial de arbitrajes. Si bien se necesitaba de medidas que detengan la hemorragia de procesos de amparos destinados a interferir el trámite de arbitrajes, tal medida no podía limitarse a un simple cambio normativo, sino que incluso debía alcanzar al precedente Fernando Canturias.

Atento a esas circunstancias, el TC dictó el precedente de Minera María Julia (STC 0142-2011-AA) que rectificó la apertura anterior del amparo, aunque volvió a cometer los errores de comprensión sobre el arbitraje como "jurisdicción”. El lado bueno es que esta vez, el TC fijó ciertos criterios y reglas adicionales que limitaron la revisión judicial de arbitrajes, cuyo eje central fue el control a posteriori de los laudos y actuaciones arbitrales.

El TC estableció que los laudos sólo podrán ser cuestionados por recursos de anulación de laudo, lo que obligó a las partes a no activar vía judiciales para interrumpir el arbitraje, sino que ahora estaban forzadas a esperar al Laudo, ya que sin él no podría activarse ninguna vía judicial de control. Para asegurar esa medida, se calificó a la anulación de laudo como una vía judicial "igualmente satisfactoria" que el amparo, por lo que la activación de aquella vía judicial exigía descartar la opción del amparo. Esto último exige una explicación más algo más detallada.

El art. 5, num. 2, CPConst dispone que no es posible iniciar un proceso de amparo para la tutela de derechos constitucionales si existe otra vía judicial que brinde una tutela "igualmente satisfactoria" o idónea. Asimismo, la $12^{a}$ Disposición Complementaria LA reconoce que la anulación de laudo cumple con ser una vía "igualmente satisfactoria que el amparo".

El calificar a la anulación de laudo como vía que brinda igual tutela que el amparo, significó tres cosas importantes:

a) Que no podrá activarse la vía constitucional de amparo para revisar los arbitrajes, ya que existía otra vía judicial igual de idónea para ese propósito, a la cual se debe acudir por mandato del art. 5, num. 2, CPConst ${ }^{(9)}$;

b) Que la vía adecuada de tutela frente a los arbitrajes es la anulación de laudos, por lo que, como ordenan los arts. 63 y 64 LA, las partes deben esperar a contar con el laudo para poder activar medidas judiciales de control y, por ende, se ven obligados a no interrumpir el trámite del arbitraje para poder activar el control judicial que corresponda;

c) Si la anulación de laudo es igualmente satisfactoria que el amparo, entonces debe entenderse que es una vía adecuada

(9) Unos años después, el TC dictó el precedente Elgo Ríos (STC 2383-2013-AA, fd. 15) que precisó el art. 5, num. 2, CPConst y, con ello, qué requisitos debía cumplir la vía judicial paralela para ser considerada como igualmente satisfactoria que el amparo. Sin embargo, eso no ha generado mayores cambios en la jurisprudencia del TC sobre el escenario anterior. 
para reparar los agravios generados contra "todos los derechos constitucionales" que son pasibles de amparo (art. 37 CPConst). Esto generaría una nueva causal de anulación de laudo adicional a las previstas en el art. $63 \mathrm{LA}$, según el cual los laudos o actuaciones arbitrales podrían ser anuladas si contravienen los derechos constitucionales. Solo si se entiende así la anulación de laudo, podría sostenerse válidamente que la anulación es una vía igualmente satisfactoria que el amparo, tal como manda la 12 Disposición Complementaria LA.

Como corolario lógico de todo lo anterior, el TC estableció que si se acudió a la anulación de laudo para la tutela de derechos constitucionales $u$ otros agravios y no se obtuvo un fallo favorable, el justiciable no podría luego discutir los mismos agravios de derechos en la vía constitucional de amparo. En efecto, el hecho de que la anulación de laudo sea una "vía judicial igualmente satisfactoria", significa que sus fallos generan cosa juzgada y, por ende, dan por concluida la controversia sobre el asunto que han evaluado. No pasaba lo mismo cuando se consideraba a la anulación de laudo como solo una "vía previa" al amparo (precedente Cantuarias), pues en tal caso, sí se podía trasladar la discusión de fondo de esa "vía previa" a la vía judicial del amparo.

No obstante, en nuestro sistema jurídico, cualquier fallo judicial que agravia o amenaza derechos constitucionales está sujeto al control que prevé el art. 4 CPConst y que permite activar procesos de amparo contra resoluciones judiciales. En efecto, en el precedente Minera María Julia, el TC precisó que cabe aplicar esta última figura contra la sentencia dictada en el proceso de anulación si allí se agravió o amenazó derechos constitucionales, es decir, contra vicios cometidos por el Poder Judicial y no contra los supuestos vicios cometidos en el arbitraje.

Al respecto, existe consolidada jurisprudencia del TC que precisa que el amparo contra resolución judicial no es un foro más para discutir o una cuarta instancia para revisar el fondo de lo ya decidido en otro proceso judicial, sino que su propósito es solo tutelar nuevos agravios contra derechos constitucional, y que nacen de las mismas decisiones judiciales y no del fondo caso resuelto. Por eso, señala que "... tratándose de un amparo contra resoluciones judiciales, la competencia de este colegiado se limita a evaluar si la actuación jurisdiccional que se reputa lesiva afecta o no los derechos constitucionales de orden procesal" (STC 0743-2001-AA, fd. 2), aunque después el TC precisó que en su conocida sentencia del caso Apolonia Ccollcca algunas reglas adicionales, entre ellas, que en esos amparos se revisan agravios o amenazas contra cualquier derecho fundamental y no solo contra aquellos que integran el debido proceso (STC 3179-2004-AA, fds. 20-21).

En resumen, la regla del precedente Minera María Julia es que las partes no podrán iniciar amparos contra laudos y actuaciones arbitrales, sino que los cuestionamientos contra ellos deberán canalizarlos a través de la vía de anulación de laudo, cuya regulación impone un control judicial a posteriori de las decisiones arbitrales. Asimismo, se prevé que solo si en la instancia judicial se cometen nuevos agravios o amenazas contra los derechos constitucionales, podrán activar luego un amparo contra tales vicios que provengan del Poder Judicial (amparo contra resolución judicial), cuyo origen está en lo decidido en el proceso de anulación y no en el asunto que fue materia del arbitraje.

El diseño jurídico anterior, supone que las vías judiciales accesibles se engranan de tal manera que el recurrir a la anulación de laudo descarta el uso de la vía de amparo. Y luego de acudir y concluir la primera opción, aún cabe iniciar un proceso de amparo contra resolución judicial, por lo que vicios que hubieran ocurrido en esa vía judicial. Esto puede ser graficado de la siguiente manera:

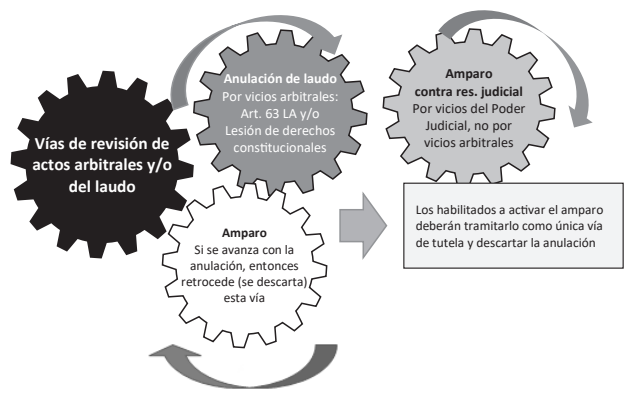

\section{Excepciones al precedente Minera María Julia}

La regla general de este precedente es que las partes acudan al recurso de anulación de laudo que tiene un diseño de revisión judicial limitado (una sola instancia y por causales taxativas) y asegura que las partes no trasladen los intereses que los llevaron al arbitraje, a la vía judicial. Por eso, el art. 62, num. 2, LA dispone que en esa vía judicial está prohibido "pronunciarse sobre el fondo de la controversia o sobre el contenido de la decisión o calificar los criterios, motivaciones o interpretaciones expuestas por el tribunal arbitral".

No obstante, puede afirmarse que ese interés de las partes se ve superado cuando 
(i) se involucran asuntos que escapan a la esfera jurídica de ellos, por ejemplo, cuando las partes pretenden afectar los derechos de un tercero; (ii) o cuando los árbitros inaplican una norma jurídica al caso concreto (realizan control difuso); o, (iii) más grave aún, cuando ellos dejan de aplicar algún precedente vinculante dictado por el TC.

Precisamente, para esos tres casos en donde los intereses de las partes en el arbitraje se ven superados, el $\mathrm{TC}$ ha dictado el precedente en comentario que establece un régimen excepcional (fd. 21). Señala que podrá activarse en forma directa el proceso de amparo contra arbitrajes cuando: (i) es interpuesto por un tercero, ajeno al convenio arbitral, alegando que lo decidido en el laudo afecta sus derechos constitucionales, (ii) el amparista sostenga que el laudo contiene un control difuso de constitucionalidad sobre leyes cuya validez ha sido ratificada por el TC, y/o, (iii) cuando se alegue que el tribunal arbitral contraviene en forma directa y frontal algún precedente vinculante del TC.

\subsection{Amparo por control difuso}

Sobre el control difuso de constitucionalidad realizado por tribunales arbitrales surgen varias dudas. Una de ellas tiene que ver con los presupuestos que deben concurrir para los jueces $\mathrm{y}$, de ser el caso, los árbitros, puedan ejercer aquel poder de control difuso y, por ende, puedan evaluar la inaplicación al caso concreto de las normas que se estimen inconstitucionales. Se trata de un asunto complejo que, sin duda ameritaría un estudio independiente ${ }^{(10)}$. Por tanto, en este espacio, nos avocaremos a una cuestión con menos variables, pero que es sumamente trascendente: hurgar en la interpretación que ha ensayado el TC para justificar la extensión del poder de control difuso a los árbitros.

El precedente de Cía. Minera María Julia habilita la activación de los procesos de amparo cuando los tribunales arbitrales realicen control difuso de inconstitucionalidad lo que. Reconoce así que los árbitros ostentan dicho poder. En un primer momento, el TC menciona como hipótesis habilitante del amparo, los casos en donde los árbitros ejerzan control difuso, inapliquen al caso concreto, normas cuya constitucionalidad ha sido ratificada por el mismo TC (fd. 21). Sin embargo, al desarrollar esa causal el TC indica que, en realidad, se habilita el amparo siempre que se realice cualquier tipo de control difuso, sea o no una norma inaplicada previamente por el TC. Por lo que se fija la siguiente regla para los árbitros:

Sólo podrá ejercerse el control difuso de constitucionalidad sobre una norma aplicable al caso de la que dependa la validez del laudo arbitral, siempre que no sea posible obtener de ella una interpretación conforme a la Constitución y además, se verifique la existencia de un perjuicio claro y directo respecto al derecho de alguna de las partes (fd. 26).

Sostiene el TC que el fundamento del poder de control difuso de los árbitros deriva de su reconocimiento como "jurisdicción arbitral” en el art. 139, num. 1, Constitución. Señala que, si los tribunales arbitrales tienen esa condición, entonces les corresponde el mismo poder de control difuso de constitucionalidad que tienen otros órganos jurisdiccionales como los jueces. Para arribar a esa conclusión, el TC recurre expresamente a una interpretación extensiva del art. 138 de la Constitución que reconoce la potestad de control difuso a los jueces ${ }^{(11)}$.

No obstante, es errado sostener que la potestad de control difuso que prevé el art. 138 de la Constitución deba ser interpretado de manera extensiva. Se trata de una potestad estatal y, en cuanto tal, necesariamente debe interpretarse de manera restrictiva. Ya vimos que, de acuerdo con el principio de distribución de Carl Schmitt (reconocido por el TC), lo que se presume y, por ende, puede interpretarse en forma extensiva, son las libertades y derechos individuales (art. 2, num. 24, lit. a, de la Constitución); mientras que la actuación de los poderes del Estado y sus potestades solo puede interpretarse de manera literal y restrictiva (art. 45 de la Constitución). Sólo hay potestades estatales allí en donde existe norma habilitante, pues las competencias no se presumen, esto es una exigencia mínima del

(10) Castillo Córdova (2006, pp. 146-156) señala los presupuestos generales para el ejercicio del control difuso de constitucionalidad en los procesos de amparo y habeas corpus, mientras que Bustamante Alarcón (2019, pp. 96-115) desarrolla con mayor detalle los elementos especiales para ejercer ese poder en la vía del arbitraje.

(11) El TC sigue el siguiente razonamiento: "Siendo el arbitraje una jurisdicción independiente, como expresamente señala la Constitución, y debiendo toda jurisdicción poseer las garantías de todo órgano jurisdiccional (como las del Poder Judicial), es consecuencia necesaria de ello que la garantía del control difuso de constitucionalidad, prevista en el segundo párrafo del artículo 138 de la Constitución, pueda también ser ejercida por los árbitros en la jurisdicción arbitral, pues el artículo 138 no puede ser objeto de una interpretación constitucional restrictiva y literal, como exclusiva de la jurisdicción ordinaria o constitucional; por el contrario la susodicha disposición constitucional debe ser interpretada de conformidad con el principio de unidad de la Constitución... más aún si ella misma (...) impone a todos y no solo al Poder Judicial el deber de respetarla, cumplirla y defenderla" (fd. 24). 
principio de separación de poderes. El principio de unidad que invoca el precedente de Minera María Julia como justificación exige lo contrario a lo que ese precedente predica: pide una lectura restrictiva y no una extensiva de las potestades estatales.

El principio de separación de poderes reconocido en la Constitución manda que las competencias se asignen por ley (arts. 43 y 45 de la Constitución). Sin embargo, en el precedente en comentario, es el TC y no el Parlamento quien ha decidido otorgar por vía pretoriana una de las potestades más trascendentes: el poder de no aplicar leyes y otras normas, el poder para superponerse a cualquier otro órgano estatal con poder legisferante, lo que es contrario al principio de división de poderes. Además, el TC otorga ese poder a los privados y a los árbitros, mas no a otros organismos estatales, lo que conlleva una enorme confusión sobre la idea misma de los sujetos de derecho público.

En suma, una interpretación desde la teoría constitucional descarta la posibilidad de extender el poder de control difuso a favor de los árbitros, tal como hace el TC. Sin embargo, una interpretación más pragmática podría inclinar la balanza a favor del reconocimiento de ese poder. $Y$ es que, si no pudieran realizar control difuso, se generaría una situación en donde los árbitros se verían forzados a aplicar leyes inconstitucionales y, por ende, a forzar a las partes a soportar esa injusticia. Esto porque en los procesos de anulación de laudo no cabe revisar el fondo de las controversias (art. 62, inc. 2, LA), ergo, no cabría controlar la aplicación de las leyes inconstitucionales que se hubiera realizado. Ello significaría que se dejaría a las partes de un arbitraje en un estado de indefensión frente a la aplicación de leyes inconstitucionales, ya que no existiría una vía jurisdiccional en donde puedan defenderse frente a normas inconstitucionales. Tal vez podría salvarse esa encrucijada si se interpreta que el proceso de anulación de laudo -ahora repotenciado como vía igualmente satisfactoria que el amparo- contiene entre sus causales la protección de derechos constitucionales lesionados o amenazas por leyes inconstitucionales (tal como prevé el art. 3 CPConst), supuesto excepcional en donde correspondería a los jueces de anulación (y no a los árbitros) definir la inaplicación o no de posibles leyes inconstitucionales. En todo caso, esta encrucijada y el debate que le corresponde, superan el propósito de estas líneas.

Por lo pronto, podemos adelantar que los jueces de amparo, y los jueces en general, no son muy dados a inaplicar posibles leyes inconstitucionales; y la práctica arbitral sigue la misma tendencia. De hecho, sólo tenemos noticia de un caso en donde efectivamente los árbitros hayan ejercido ese poder de control difuso de constitucionalidad. Además de los vicios constitucionales antes indicados, la inaplicación de una ley de orden público al caso concreto puede viciar al laudo de tal manera, que haría bastante predecible la eventual nulidad del laudo y la consecuente responsabilidad de los árbitros.

En efecto, en el arbitraje voluntario entre el Ministerio de Trabajo y su Sindicato Único (Expediente de negociación colectiva 426-2018-SERVIR/GDSRH-NC), el Tribunal Arbitral inaplicó una ley de presupuesto que, a juicio del colegiado, afectaba el derecho constitucional a la negociación colectiva de los trabajadores ${ }^{(12)}$. Es decir, particulares decidieron que una ley dictada por el Parlamento no se aplique a un caso concreto. Los árbitros tendrían el poder de quitar fuerza de ley a un mandato legal. Formalmente es una decisión impecable, amparada en el precedente del TC. Incluso, puede ser que efectivamente la ley inaplicada contravenga la Constitución. Sin embargo, creemos que tal empoderamiento de los árbitros es inconstitucional, aunque esté avalada por nada menos que el mismo TC. El poder otorgado a los árbitros para que ejerzan la potestad pública de control difuso, sin que exista texto legal o constitucional que así lo autorice, constituye un exceso que contraviene el principio de división de poderes: el TC carece de competencias para "presumir" que la Constitución otorga poderes de control difuso a los árbitros. Esperamos que este caso sea materia de un proceso amparo que llegue hasta el TC para que éste tenga la oportunidad de corregir sus errores.

Vinculado con lo anterior, existen otros problemas que deberían analizarse, por ejemplo, cuando el TC ya inaplicó una norma en vía de control difuso de constitucionalidad, ¿los árbitros podrán replicar ese control? ¿Estarán jurídicamente obligados a seguir los criterios del TC en virtud del art. VI del Título Preliminar del CPConst? Asuntos trascedentes que exceden el propósito perseguido en estas líneas. Aquí nos basta con que haya quedado claro que, en virtud del precedente de Minera María Julia, es posible activar la vía de amparo de modo directo contra laudos que hubieran ejercido control difuso de constitucionalidad.

(12) https://storage.servir.gob.pe/negociacioncolectiva/Laudos/216_426_2018_SERVIR_GBSRH_NC.pdf, recuperado el 1 de noviembre de 2020. 


\subsection{Amparo por violar otro precedente}

El otro supuesto que permite acudir de modo directo al amparo se daría en aquellos casos en donde se alegue que el tribunal arbitral contravenga algún precedente del TC. El no aplicar un precedente no significa una condena de muerte para el eventual laudo que hubiera incurrido en tal atrevimiento, sino que incluso en ese supuesto pueden existir razones legítimas que justifiquen el apartamiento del precedente y, con ello, que el control constitucional del amparo deba convalidar el laudo arbitral. Para explicar mejor esto, es conveniente un breve repaso sobre la noción de precedente.

En términos bastante generales, podemos decir que en el common law los precedentes se refieren a las reglas que se derivan de los principios, explícitos e implícitos, que se elevan como criterios centrales de las decisiones, de ahí que allá sea un asunto central la identificación de esos principios que constituyen la ratio decidendi de los casos resueltos ${ }^{(13)}$.

En cambio, en nuestro país, los precedentes están contenidos en mandatos que fija el TC de modo directo y general en sus sentencias, al señalar específicamente: "la siguiente regla constituye precedente(...). Aunque muchas veces para comprender tales reglas es necesario recurrir a los demás elementos de esas mismas sentencias que nos indican el fundamento (ratio decidendi) que subyace en tales reglas y, por ende, nos permiten determinar sus alcances.

Son enormes las diferencias entre el precedente del derecho inglés y el peruano. Sin embargo, existen algunas similitudes que nos habilitan a trasladar ciertas nociones a nuestro sistema, sobre todo aquellas que sirven para mantener el dinamismo de un sistema jurisprudencial, como la técnica del distinguishing reconocida también por nuestro TC (STC 3361-2004-AA, fd. 5 y STC 4361-2004-AA, fd. 5).

Duxbury (2008, pp. 113-116) explica que esta técnica consiste en diferenciar los hechos que fueron relevantes e intrascendentes en una decisión judicial, a fin de demostrar que un caso presenta diferencias de tal magnitud que justifica que el criterio de esa decisión previa no le alcance. Pero, agrega, esto no significa que los jueces puedan burlar los precedentes cuando les convenga, sino que la actividad de distinguir no debe perturbar la autoridad del precedente, pues no se declara que éste sea errado, sino que es correcto solo que es inaplicable bajo otras circunstancias similares, pero con diferencias significativas.

De acuerdo con lo anterior, un laudo arbitral que se aparte de las reglas establecidas en un precedente del TC no sería inválido por ese solo hecho, sino que podría encontrar justificación, y ser convalidado en la vía del amparo, si contiene una adecuada aplicación de la técnica del distinguishing.

Lo que tratamos de demostrar es que el precedente de Minera María Julia solo ha previsto causales para la procedencia de amparos contra arbitrajes (actuaciones o laudos), pero el hecho de que concurran tales causales no significa, por sí solo, que las demandas de amparo que se activen, necesariamente, deban declararse fundadas. En todo caso, al igual que en el apartado anterior, desconocemos de prácticas en donde los tribunales arbitrales se hayan atrevido a apartarse de precedentes del TC.

\subsection{Los terceros tutelados}

Lamentablemente, sí abundan casos de terceros afectados por laudos dictados en arbitrajes que le fueron ajenos, pues fue la técnica usual de supuestas organizaciones criminales lideradas por Rodolfo Orellana y Vicente Díaz Arce. Frente a tales acciones, los terceros tuvieron que activar amparos para defenderse contra esos laudos ajenos que disponían de sus derechos. Así pasó con el caso de Giovanni Paredes (STC 3841-2012AA) en donde el TC advirtió de la lesión de sus derechos constitucionales porque un laudo disponía de su propiedad sobre el conocido Camal de Yerbateros, a pesar de que fue dictado en un arbitraje tramitado entre dos empresas, sin intervención del Sr. Paredes ${ }^{(14)}$.

(13) Cross y Harris (2012, p. 96) señalan que "la ratio decidendi de un caso es cualquier regla de Derecho que haya sido implícita o explícitamente considerada por el juez como necesaria para llegar a su conclusión, teniendo en cuenta la línea de razonamiento adoptada por dicho juez". En el influyente trabajo de Goodhart (1930, p. 165) se advertía que la ratio decidendi "no es la regla de derecho establecida por el tribunal, o la regla enunciada(...) lo que necesariamente constituye el principio [ratio] del caso(...) puede que no se pronuncie una norma de derecho en la sentencia, o que la norma, cuando se mencione, sea demasiado amplia o demasiado estrecha", por lo que concluía que la determinación de la ratio decidendi se debe fundamentar en "los hechos tratados por el juez como materiales [relevantes] y su decisión basada en ellos", es decir, la conexión que permite ir de una al otro será el principio [ratio] aplicado al caso.

(14) Así también parece que pasa en el caso Cruz Gálvez Hernández (ATC 6721-2015-AA) en donde el TC ha ordenado al juez de primera instancia que admita una demanda de amparo formulada por un tercero contra un laudo dictado en un arbitraje en donde no fue parte y que, sin embargo, dispondría de su derecho de propiedad. 
Casos de este tipo y similares inspiraron la excepción que habilita el amparo de terceros contra actuaciones arbitrales. Sin embargo, se trata de una regla que necesita ser precisada para que no se generen otras tergiversaciones, como creer que todo tercero que se sienta "afectado" por arbitrajes está habilitado para cuestionarlo judicialmente. Para eso debemos detectar, aunque sea de manera genérica, las clases de terceros que estaría habilitados y los que no, para activar el amparo.

Lo primero que debemos aclarar es que en lo sucesivo nos referiremos a los terceros propiamente dichos. Es decir, a los sujetos que son ajenos a la relación jurídica material o contractual y que, sin embargo, podrían ser afectados con los efectos de hecho o jurídicos de esa relación ajena. Este es un supuesto distinto a los sujetos que sí son parte de los arbitrajes, a pesar de generarse ciertas dudas sobre esa condición. Tal sería el caso, por ejemplo, de las partes no signatarias del convenio arbitral o del contrato que, a pesar de la ausencia de sus rúbricas en el acuerdo, sí deben ser considerados como parte del mismo porque se trata de un grupo de empresas vinculadas, porque participaron en la negociación o ejecución del acuerdo, porque el acuerdo forma parte de un único negocio más complejo, etc. Además, hay otros casos de arbitrajes en donde hay múltiples partes, en donde se debate el inicio de posibles casos con algunas partes o con todas ellas, el trámite de procedimientos paralelos, la consolidación de casos, la condición de demandado o demandante que deben tener u otros sujetos, las consecuencias y alcances de la exigibilidad del laudo, entre otras cuestiones ${ }^{(15)}$.

En todos esos casos, los sujetos que integran la relación material y que tienen la condición de parte, deberán acudir a la vía de la anulación de laudo, tal como manda el art. 63 , inc. 1, LA que, precisamente, habilita esa vía a las "partes".

El precedente de Cía. Minera María Julia, ha habilitado el proceso de amparo a los terceros, a los sujetos que son ajenos a la relación material y que, sin embargo, dicen ser afectados por el laudo dictado sin su intervención. Por lo que nos avocaremos a identificar la clase de terceros a los que se refiere el precedente.

Los terceros coadyuvantes (art. 97 del Código Procesal Civil) no son los legitimados según el precedente. Estos terceros tienen una relación de prejudicialidad-dependencia con respecto a la relación discutida en el proceso. La decisión que recae sobre la relación jurídica material de las partes involucradas en el proceso actúa como hecho constitutivo, modificativo o extintivo de la relación del tercero, que tiene un nexo de dependencia frente a aquélla, por eso, en el proceso judicial se hablita la intervención del tercero, pero solo en defensa de los derechos de la parte a la que "ayuda" y no de sus propios derechos. Por ejemplo, el subarrendatario no es titular de la relación jurídica discutida en un proceso de desalojo entre propietario y arrendatario, pero es indudable que la relación jurídica de la que sí es titular depende de la controversia, de modo que la futura sentencia le afectará de modo reflejo.

Una sentencia o un laudo sobre una situación jurídica puede legítimamente generar lo que se conoce como "efectos reflejos" sobre otras relaciones de titularidad de terceros no intervinientes en el litigio. Eso no significa que se haya juzgado la relación jurídica del tercero sin su intervención, sino que se juzgó efectivamente las relaciones existentes entre las partes del litigio. Lo que pasa es que esa relación es el presupuesto o condicionante de otra que es de un tercero y, en tal sentido, tiene un efecto reflejo en su situación.

Para que esto sea posible, el tercero debe haber pactado libremente una relación jurídica que dependa de otra relación ajena (tal como ocurre con los subarrendatarios). Por tanto, en virtud de la autonomía de la voluntad, las partes o el tribunal arbitral constituido por éstas, legítimamente podrán negar la intervención de estos terceros coadyuvantes al arbitraje sin afectarlos jurídicamente, pues no se discuten sus derechos. A estos terceros sólo les queda aceptar la situación jurídica establecida entre las partes por el tribunal arbitral, que les será oponible, que podrá incidir sobre su propia relación jurídica dependiente. Todo esto indica que este tipo de

(15) El trabajo más conocido en la materia es del de Hanotiau (2005, pp. 2-3) que, desde el inicio, enumera las posibles controversias en torno a la identificación de las partes del arbitraje. También puede verse el trabajo de Born (2014, pp. 1404-1524) que tiene una amplia referencia de casos reales y Caivano que enumera los diferentes tipos de problemas materiales y procesales que se generan en los arbitrajes con relaciones jurídicas múltiples (2007, pp. 69-118). En nuestro país, Mori y Galluccio (2012, pp. 75-203) hacen un estudio de las partes no signatarias a las que se puede extender el convenio arbitral mediante las teorías del levantamiento del velo societario y del grupo de sociedades; a su vez, Mori (2016, pp. 149-164) hace un estudio jurisprudencial sobre las partes no signatarias, mientras que Matheus (2018, pp. 69-78) busca interpretar los alcances de nuestra regulación sobre partes no signatarias a partir de los actuales estándares internacionales sobre la materia. 
terceros no son los afectados a los que se refiere el precedente Minera María Julia.

Distinta es la situación del tercero que no es parte de la relación contractual, ni aceptó tener una relación jurídica que dependa de otra que le es ajena y que, a pesar de eso, ve eliminado o mermado uno de sus derechos de modo directo, y no reflejo. Estos serán los únicos terceros legitimados al que se refiere el precedente de Minera María Julia. Estas situaciones se caracterizan porque se usa una relación jurídica totalmente ajena o desconocida por un sujeto para así eliminar uno de sus derechos a través de un arbitraje que le es ajeno. Este accionar malicioso se materializa a través de un arbitraje de cuyo trámite no se emplaza al tercero para ejerza su defensa $y$, en caso esto ocurra, el tercero no estaría obligado a ingresar a aquel arbitraje por no haberlo pactado.

Aquí debe tenerse mucho cuidado, pues puede ocurrir que alguien que se creía ajeno a una relación jurídica y la controversia arbitral vinculada a ella, sin embargo, sea incorporado al proceso como "parte no signataria", es decir, como parte de la relación jurídica, aunque no haya firmado su intervención en ella, tal como prevé el art. $14 \mathrm{LA}^{(16)}$.

Al respecto, el TC ha precisado que no se trata de un "tercero", sino de un sujeto que es parte del proceso y, como tal, debe ejercer sus defensas al interior de esa vía procesal y luego, de ser el caso, recurrir a un control posterior en vía de anulación de laudo. Ciertamente, en el caso Deporsur (STC 1989-2018-AA), la empresa fue incorporada como parte no signataria del arbitraje. Sin embargo, nunca se apersonó al arbitraje, ni ejerció defensa alguna, sino que acudió de modo directo al amparo alegando ser uno de los terceros que recoge el precedente de Minera María Julia. EI TC declaró improcedente tal demanda de amparo al estimar que no era un tercero ajeno al arbitraje, si no que tuvo la condición de parte y que incluso pudo defenderse.

Pero el asunto es aún más complejo, pues litigantes inescrupulosos podrían usar la legítima figura de la "parte no signataria" para incorporar a arbitrajes a auténticos terceros, a sujetos ajenos a la relación material discutida, con el claro propósito de despojarle de sus derechos a través de una nueva modalidad de arbitrajes fraudulentos. De manera que, resulta esencial una adecuada comprensión de esa figura y de la relación material debatida para prevenir excesos e indebidas conversiones de terceros en parte de una causa arbitral.

O, como lo estudia Consolo (2012, p. 844), también pueden darse casos de terceros que, sin embargo, piden intervenir en un arbitraje en curso para plantear sus propias pretensiones, y las partes, junto al tribunal arbitral, consienten y/o deciden admitirlo. En tal caso, se generaría un nuevo convenio arbitral y una nueva relación procesal frente a los árbitros, ese tercero dejará de serlo, por voluntad de las partes, para adquirir la condición de parte y, por ende, se sujetará a las mismas reglas aplicables para las otras partes, como la revisión a posteriori de las actuaciones arbitrales y mediante anulación de laudo.

\subsection{Sigue. Los terceros tutelados}

Los usos fraudulentos del arbitraje fueron posibles por un desconocimiento de nociones básicas del derecho civil. Por ejemplo, en virtud del principio de relatividad (arts. $1352 \mathrm{y}$ 1363 del Código Civil - "C.Civil"), las partes de un contrato solo pueden vincular a sus esferas jurídicas si media consentimiento. Incluso en los casos de contratos a favor de tercero (arts. 1457 y 1458 , C.Civil) o de promesa de hecho de tercero (art. 1470 C.Civil) se necesita del consentimiento del tercero para incidir sobre su esfera jurídica. Lo mismo pasa con la figura de la venta de bien ajeno que requiere el consentimiento del titular del bien que interesa adquirirse (arts. 1537-1541, C.Civil).

Si a pesar de eso, se celebra un contrato para alterar la esfera jurídica ajena sin tener legitimación para disponer de esas situaciones ajenas, ese acuerdo será inoponible para los titulares de tales situaciones, pues no se podrá alterar su esfera jurídica sin su voluntad. Es decir, si se mira esta situación desde una perspectiva totalmente civilista, un contrato no puede disponer de derechos de un tercero salvo que se cuente con su consentimiento expreso. La misma situación debería seguirse en los laudos: un laudo no puede afectar la esfera jurídica de un tercero ajeno a la relación obligacional de la cual surgió la controversia materia de decisión arbitral. Si se hubiera entendido esto, los árbitros y los registradores que no estaban

(16) Artículo 14 LA. Extensión del convenio arbitral.

El convenio arbitral se extiende a aquellos cuyo consentimiento de someterse a arbitraje, según la buena fe, se determina por su participación activa y de manera determinante en la negociación, celebración, ejecución o terminación del contrato que comprende el convenio arbitral o al que el convenio esté relacionado. Se extiende también a quienes pretendan derivar derechos o beneficios del contrato, según sus términos. 
coludidos y a quienes se presentaron los arbitrajes fraudulentos para despojar o incidir sobre derechos de terceros, hubieran advertido que las actuaciones arbitrales no podían tener ninguna eficacia sobre los terceros, que tales actos les eran inoponibles ${ }^{(17)}$.

Pero el descaro de los arbitrajes fraudulentos no quedo ahí, sino que incluso buscó -y muchas veces, obtuvo- la colaboración judicial. Varios terceros se enteraron de esos arbitrajes y laudos fraudulentos cuando les notificaron las demandas de caducción de laudo que les conminaban a desalojar el bien porque un laudo -que hasta ese momento desconocían- había eliminado o preterido sus legítimos derechos sobre tal bien. Ciertos jueces ordenaban la ejecución de esos laudos, sin mayor análisis de su legitimidad. Sostenían que tenían la calidad de cosa juzgada y, bajo esa bandera, no tenían ninguna opción para cuestionarlos y negar su ejecución.

Tal respuesta también evidenciaba que los mismos jueces desconocían instituciones procesales básicas. Ciertamente, los laudos tienen la calidad de cosa juzgada que se deriva de la cualidad "jurisdiccional" del arbitraje. Eso permite que los laudos, al igual que las sentencias, no se pierdan en un kafkiano laberinto de interminables revisiones, anulaciones o revocaciones judiciales. La seguridad jurídica exige dar por terminado de modo definitivo el pleito, de modo que nadie lo pueda revisar. Cuando eso ocurre, la decisión tiene valor de cosa juzgada. Eso hace que lo decidido se torne en inmutable.

La cosa juzgada hace inmutable la decisión, pero los efectos de esa decisión definen sobre qué asunto (límites objetivos) y sobre quiénes (límites subjetivos) recae tal inmutabilidad. A pesar de confundir entre cosa juzgada y límites subjetivos de la sentencia, el penúltimo párrafo del art. 123 del Código Procesal Civil advierte que las únicas situaciones jurídicas que están en aptitud de adquirir inmutabilidad por la cosa juzgada son aquellas situaciones creadas por una sentencia respecto de las partes de un proceso o respecto de quienes intervienen en las causas.

Por ejemplo, A y B son partes de un proceso sobre mejor derecho de propiedad y duplicidad de partidas, donde A gana por tener la partida registral más antigua. Tal sentencia será inmutable en la relación entre $\mathrm{A}$ y $\mathrm{B}$, pero de nada servirá para sacar del inmueble a $C$ quien dice ser el propietario por prescripción y no intervino en aquel proceso. Los límites subjetivos de la sentencia permiten vincular a las partes, pero no permiten extenderla a un sujeto que no tuvo intervino ni tuvo contradictorio en ese proceso. El derecho de defensa exige otorgar la posibilidad de contradictorio al titular de la esfera jurídica que vaya a alterase.

Por consiguiente, la sentencia o laudo que hubiera definido la situación entre A y B mantendrá su carácter inmutable, su valor de cosa juzgada, entre esas partes. Pero eso no significa que pueda alterar, o que sea inmutable respecto de terceros como C. Esto debieron advertir los jueces: la cualidad de cosa juzgada no permite extender los alcances subjetivos de los laudos para alterar los derechos de terceros, los jueces debieron declarar la inejecutabilidad o inoponibilidad de esos laudos sobre terceros ajenos, sin que eso signifique afectar la cosa juzgada.

Parece que muchos jueces que tramitaban los pedidos de ejecución de laudos manifiestamente fraudulentos desconocían estas nociones. Sostenían que los laudos tenían la calidad de cosa juzgada y, por ende, eran inatacables, sin advertir que los límites subjetivos de las decisiones -que impide alterar derechos de quienes no son parte- constituyen una exigencia ínsita y no ajena a la naturaleza de la cosa juzgada. Aunque debemos cuidar de no desnaturalizar esto último.

En efecto, como ya advertimos, no toda persona que se considere "afectada" con una sentencia o laudo dictados en una causa ajena, puede sostener que, debido a los límites a la eficacia subjetiva de laudos y sentencias, debe ser totalmente ajeno a esas decisiones. $Y$ es que no basta con una mera incidencia del fallo sobre un tercero para considerar que excede sus límites subjetivos, éste solo estará agraviado en sus derechos con una decisión ajena si le genera un agravio jurídico directo, y no una incidencia refleja sobre su situación ${ }^{(18)}$.

(17) Una referencia a la manera de operar de esa clase de arbitrajes puede verse en los artículos de Davelouis (2014). De hecho, los autores defendieron distintas causas en donde ese fue el proceder denunciado por los afectados en la vía penal y en sendos procesos de amparo. Sin embargo, también existieron otras modalidades de estafa que implicaban la falsificación de las firmas de los propietarios.

(18) En ese sentido, Liebman (1946, p. 177) señala que "no todos los terceros perjudicados por la sentencia tienen la facultad de rechazar su efecto (...) [eso] es admisible sólo si se apoya en un interés jurídico. Por eso, todos los terceros que sufren por la sentencia un simple perjuicio de hecho no tendrán aquella facultad; la cual corresponderá sólo a los que son titulares de un derecho incompatible con la sentencia, estando, por consiguiente, jurídicamente perjudicados por ella. Dentro de tales supuestos están los 'terceros jurídicamente indiferentes' (ej., todos los acreedores del vencido) que son perjudicados de hecho por la sentencia y que no podrán, 
Por último, se debe resaltar que la posibilidad de que un tercero cuestione la eficacia de un laudo que le resulta ajeno porque no fue parte del convenio arbitral que lo generó y/o del convenio arbitral, en modo alguno puede significar un control judicial sobre la legitimidad de lo decidido en el fondo del caso. Simplemente, significará que el Juez verificará que lo que hubiera decidido el laudo arbitral contra el tercero ajeno, no podrá serle eficaz u oponible, esto es, no podrá alterar su esfera jurídica.

Esta es una descripción bastante genérica de un asunto mucho más complejo que hemos atendido en otros lugares y a los cuales nos remitimos.

\section{Sobre los alcances del art. 3 LA}

Con estos elementos es más sencillo el análisis del art. 3 de la Ley de Arbitraje y de las manifestaciones del principio de mínima intervención judicial.

\subsection{Articulación de vías arbitrales y judiciales}

Como señala el Juez inglés Lord Mustill, citado por Redfern y Hunter (2016, p. 428), la relación entre arbitraje y corte judicial puede ser entendida como una carrera de relevos. En la etapa inicial, el Poder Judicial puede tomar medidas preventivas para asegurar la eficacia de lo que se discutirá una vez abierto el litigio. Pero luego los árbitros toman las riendas, cogen la posta de la cautelar decidida por el juez, y llevan el proceso hasta la resolución de la causa. Finalmente, le devuelven la posta al Juez para que verifique si la carrera fue llevada con justicia y, en su caso, para que le presten sus poderes coercitivos a fin de ejecutar lo decidido.

Ya vimos cómo es que se articula arbitraje y su mecanismo ordinario de control (la anulación de laudo), así como sus vías excepcionales de control judicial (amparo). De modo que resulta necesario referirnos al apoyo judicial que se requiere durante la carrera arbitral. Por ejemplo, para la declaración de un testigo, el tribunal arbitral necesitará del apoyo judicial porque no tiene poderes sobre una persona que no suscribió el convenio arbitral y, además, no tiene coerción que lo obligue a comparecer. Lo mismo impide que el tribunal arbitral ejecute cautelares con mandatos que involucran a terceros, como la orden a un banco de que congele una cuenta, la toma de muestras (para pericias) de productos ubicados en el almacén de un tercero o el acceso a documentos en poder de terceros.
En efecto, lo más común es que se necesite de la colaboración del Poder Judicial para hacer uso de sus poderes coercitivos, de su poder para imponer sus decisiones sobre terceros ajenos al arbitraje (que no son afectados, pero que pueden colaborar o facilitar con ciertas actuaciones) o sobre partes renuentes a cumplir los mandatos arbitrales. Eso pasa, por ejemplo, con la actuación de ciertas pruebas en poder de terceros o en poder de una de las partes, pero que se niega a entregar (art. 8 , num. 1 y art. 45). También pasa con la ejecución de mandatos cautelares dictados en arbitraje que necesitan de ejecución forzosa (art. 8, num. 2, LA, art. 4 , nums. 4 y 5 , LA y art. 47, num. 9, LA) pues, por ejemplo, varias entidades financieras se niegan a ejecutar mandatos cautelares de embargo en forma de retención sobre cuentas de sus clientes, si tales mandatos provienen de tribunales arbitrales y no de un juez. Lo más usual es que se necesite de la colaboración judicial para la ejecución forzosa de laudos nacionales e internacionales (art. 8, num. 3, art. 59, num 3 y art. 68) o de laudos extranjeros ya reconocidos (art. 8, num. 6, art. 74, art. 77, art. 78 y $14^{\mathrm{a}}$ Disposición Complementaria).

De cualquier modo, en virtud del derecho a la tutela jurisdiccional efectiva, estimamos que las partes no necesitan de la autorización expresa del tribunal arbitral para que puedan solicitar de modo directo la colaboración judicial dirigida a ejecutar las decisiones arbitrales, siempre que exista un incumplimiento que efectivamente justifique el pedido de colaboración dirigido al juez y que este estime que el mandato no contraviene el orden público o leyes prohibitivas expresas que limitan siempre la autonomía de la voluntad (art. 2, inc. 14 y art. 62, de la Constitución; art. 45, inc. 3, LA). En efecto, el Juez debe evaluar la licitud de la medida arbitral, pues no es un mero colaborador que ejecuta los comandos arbitrales, sino que

por consiguiente, alzarse contra ella". O, como ejemplifica Chiovenda (1954, p. 475) "todos, pues, están obligados a reconocer la cosa juzgada entre las partes; pero no pueden ser perjudicados por ella. Por perjuicio se entiende no un perjuicio de mero hecho, sino un perjuicio jurídico. Por ejemplo, el heredero puede ser perjudicado de hecho por los fallos obtenidos por tercero contra su causante; y sin embargo, él está sometido a esos fallos; el acreedor es perjudicado de hecho por la cosa juzgada que reconoce nuevas deudas de su deudor, pero él no puede impedir por ello los efectos que le perjudican". 
siempre sus actuaciones deben sujetarse dentro del margen de la constitucionalidad.

No sostenemos que, en vía de colaboración, los jueces puedan invalidar actuaciones arbitrales. Lo que decimos es que no podrán ejecutar medidas que excedan sus propias competencias. Por ejemplo, si un mandato arbitral ordena la actuación de ciertas pruebas que requieren el levantamiento del derecho al secreto de las comunicaciones, no podrá ser ejecutado por un juez, ya que él mismo tiene limitada esa posible intervención sobre el indicado derecho constitucional. Los jueces pueden intervenir sobre las comunicaciones sólo en los casos previstos en la ley (art. 2, num. 10, de la Constitución) la misma que solo habilita al Ministerio Público a solicitar tal intervención, con el propósito de perseguir ciertos delitos y siempre que se cumplan ciertos requisitos (art. 231 del nuevo Código Procesal Penal), que no cumplen los tribunales arbitrales.

También se requiere la colaboración judicial para algunas medidas arbitrales foráneas que necesitan del poder estatal para adquirir juridicidad en el territorio peruano. Eso pasa, por ejemplo, cuando se pide el reconocimiento de medidas cautelares y/o de laudos extranjeros (art. 8, num. 5, art. 48, num. 4 , art. 74 y art. 75 , num. 8,76 y 78 ) que buscan surtir efectos, ser vinculantes, en el Perú.

\section{2. ¿La anulación de laudo como vía inadecuada para los terceros y las partes?}

La LA reconoce que el Poder Judicial es la entidad de revisión de validez de los arbitrajes a través de la anulación de laudos nacionales e internacionales (arts. 62-66, LA) y por causales taxativas. Y ya verificamos que el precedente de Minera María Julia abre la posibilidad de revisar la validez de laudos en vía de amparo para tres supuestos excepcionales como el caso de terceros afectados en sus derechos por laudos o actuaciones arbitrales ajenas.

El tránsito por la vía de anulación de laudo sólo puede imponerse a las partes de un proceso y no a los terceros, lo que tiene una explicación más profunda que la simple previsión en el referido precedente. $Y$ es que las partes del convenio arbitral voluntariamente renunciaron a que su causa sea vista en el sistema judicial, siendo por ende legítimo que ellos deban sujetarse a un proceso judicial de instancia única y de cognición limitada como es la anulación del laudo ${ }^{(19)}$. Por consiguiente, imponer al tercero ajeno al convenio arbitral que recurra a la instancia única del recurso de anulación de instancia única para lograr la invalidez y/u inoponibilidad de un laudo, supondría una lesión de su derecho a la doble instancia y su derecho al juez natural. Se estaría imponiendo al tercero que la resolución de sus asuntos, que no ha acordado sustraer del ámbito judicial, se vean en una sola oportunidad y por jueces del recurso de anulación a los cuales no acordó someterse.

No obstante, el TC ha abierto la posibilidad de que las partes de un arbitraje también puedan acudir de modo directo a la vía de amparo y no a la anulación de laudo. Así, en un proceso de arbitraje en donde se discutía el quantum de la indemnización justipreciada de una expropiación, se emitió un laudo arbitral que ordenaba el pago de cierto monto, bajo apercibimiento de caducidad de la expropiación. Como la entidad no pagó en el plazo fijado, el mismo tribunal arbitral ejecutó su apercibimiento y declaró la caducidad de la expropiación. El Estado planteó demanda de amparo y el TC consideró que ella no contradecía los criterios del precedente de Minera María Julia porque ésta no preveía la tutela contra actuaciones arbitrales distintas al laudo que desnaturalizaran su ejecución. Por tanto, la demanda de amparo era procedente en ese extremo porque no contradecía el precedente, pero igual fue desestimada por el TC porque las actuaciones arbitrales impugnadas no desnaturalizaban lo decidido en el laudo (RTC 8448-2013-AA, fds. 11-12).

La justificación del TC para estatuir ese distinguishing al precedente, es bastante pobre. El argumento del Estado era que el

(19) Así lo tiene dicho el mismo TC: “(...) la decisión de una persona para someter una controversia determinada al conocimiento de un tribunal arbitral (...) conlleva una renuncia expresa a que dicha litis sea resuelta a través del órgano constitucional investido por la Constitución para ejercer la potestad jurisdiccional y, por tanto, que su desarrollo se realice con determinadas garantías formales que integran el derecho al debido proceso; y ii) además del derecho a ser juzgado por un juez predeterminado por la ley, cuya renuncia es ínsita a la decisión de someterse a un tribunal arbitral, otra de las garantías formales del debido proceso a las que se renuncia con dicha decisión lo constituye el derecho a la pluralidad de instancias, cuya titularidad y ejercicio está previsto sólo para el caso de las personas que deciden someter sus diferencias ante el Poder Judicial. En sede arbitral, en efecto, no está constitucionalmente garantizado que una determinada controversia necesariamente tenga que ser resuelta por una instancia plural" (STC 1755-2007-AA fd. 3 y 5 y STC 3261-2005-AA, fd. 4 y 5 ). 
apercibimiento de caducidad contenida en el laudo y ejecutado después, era lo que justificaba su pedido de tutela judicial. Siendo así, el TC podría haber advertido, sin necesidad de hacer una distinción, que la entidad estatal tuvo abierta la opción de acudir a la vía ordinaria de anulación de laudo para cuestionar lo que, a juicio de la entidad, era un apercibimiento inválido contenido en el laudo. Por tanto, el TC debió declarar que el amparo era improcedente ya que la entidad tuvo la oportunidad de activar la vía ordinaria y no lo hizo.

La razón adecuada para hacer la distinción que habilite a las "partes" a acudir al amparo debe ésta: existe una resolución arbitral posterior al laudo que desnaturaliza su ejecución y alcances, pero que ya no puede ser objeto de un recurso de anulación de laudo porque, por ejemplo, se expidió fuera del plazo para interponer esa demanda. Es decir, solo ante la imposibilidad de usar la vía ordinaria, cabría que las partes activen el amparo. Tal pareció ser el caso de Luz del Sur (STC 2630-2019-AA) que inició un proceso de amparo solamente dirigido a cuestionar resoluciones arbitrales de ejecución que no tuvo oportunidad de cuestionar en el recurso de anulación de laudo. Si bien el TC desestimó la demanda de amparo, consideró que era procedente en virtud del distinguishing antes indicado.

EI TC también ha buscado instaurar un distinguishing para el caso de terceros no afectados por laudos, sino por otras actuaciones arbitrales. Tal podría ser el caso, por ejemplo, del tercero afectado con un mandato arbitral que, para dirimir una controversia ajena, ordena la actuación de pruebas que agravian su secreto de las comunicaciones, su secreto profesional o alguna otra libertad protegida. ¿Cómo podrá defenderse el tercero? El diseño del precedente de Minera María Julia considera la hipótesis de laudos que afecten derechos de terceros y no otras actuaciones arbitrales previas o posteriores que afectan a terceros, lo que, como reconoce el mismo $\mathrm{TC}^{(20)}$, da espacio para hacer un distinguishing que les habilite a activar de inmediato al amparo, sin esperar al laudo.

No obstante, también podría alegarse que esos terceros podrán defender sus derechos constitucionales ante el juez que colabore con ejecutar la actuación arbitral (por ejemplo, pruebas o cautelares), lo que podría descartar el uso del amparo como vía de defensa o, en todo caso, que recién lo habilitaría si el juez colaborador no tutela los derechos constitucionales del tercero, de modo que éste deba activar un amparo contra la resolución judicial de tal juez. El hecho que el único criterio del TC vinculado al asunto no considere esta última y natural hipótesis, indica que el asunto no se resuelve aún de forma definitiva, sino que se necesitan de mayor precisión en la práctica jurisprudencial o un mayor estudio de la doctrina.

Además, conocemos de otros casos judiciales en donde parece razonable que las "partes de la relación jurídica" invoquen la aplicación de un distinguishing al precedente de Minera María Julia, para poder activar procesos de amparo contra arbitrajes y no procesos de anulación de laudo. La urgencia del caso y las pruebas de que se yergue un arbitraje fraudulento, son lo que ha justificado crear esas distinciones. Aunque, cabe aclarar, se trata de casos que aún se encuentran en primera instancia judicial(21).

La realidad es rica en ejemplos, pues se pueden dar situaciones distintas a las enumeradas que también requieran de la

(20) En una resolución (no sentencia) ya citada el TC señaló que: “(...) el referido precedente vinculante no resulta aplicable a los supuestos en los que, como ocurre en el presente caso, el alegado agravio a los derechos fundamentales proviene de resoluciones arbitrales distintas al laudo arbitral, concretamente de resoluciones arbitrales expedidas en la fase de ejecución del laudo arbitral" (RTC 8443-2013-AA, fd. 11). El TC también hace distinguinshing para el caso de medidas cautelares dictadas al interior de un arbitraje aún no concluido, habilitando así la posibilidad de que el tercero active el amparo (STC 3482-2013-AA, fds. 6-8).

(21) En la Corte Superior de Justicia de Lima (Expediente 6105-2016), tenemos el caso de una persona que tenía una pretensión de indemnización extracontractual por un supuesto accidente padecido dentro de un supermercado. Sin convenio arbitral alguno, dicha persona inició un arbitraje ante la institución arbitral llamada Colegio Nacional de Conciliadores Extrajudiciales del Perú que, según sus reglas arbitrales, designó un árbitro único que, de inmediato ordenó trabar medida cautelar de embargo sobre las cuentas de la empresa. Eso motivó que la empresa no espere a la continuación de ese fraudulento arbitraje para iniciar su demanda de anulación de laudo, sino que formule de inmediato demanda de amparo. El Juez de primera instancia ha declarado fundada la demanda de amparo, precisamente, haciendo la distinción del precedente.

En la Corte Superior de Justicia de Amazonas (Expediente 0215-2020), un Consorcio tenía un contrato de la Municipalidad Provincial de Moyobamba con un convenio que establecía un arbitraje sometido a las reglas y administración de los centros arbitrales de la PUCP o del OSCE. Sin embargo, la Municipalidad inició un arbitraje ante el Centro de Arbitraje Latinoamericano y de Investigaciones Jurídicas y, a pesar de las oposiciones de la parte demandada, insistió en asumir competencia y en designar a los árbitros del caso. Eso motivó que el Consorcio formule demanda de amparo que suspenda el trámite del arbitraje, causa en donde el Juez ha dictado una medida cautelar que suspende el trámite del cuestionado proceso arbitral. 
intervención judicial, lo que debe evaluarse caso por caso y con una visión muy restringida. Por ejemplo, en el caso National Iranian Oil Company (NIOC) contra Israel, se pactó el sometimiento al Reglamento de Arbitraje de la Cámara de Comercio Internacional de París ("CCl”), pero no se acordó el lugar del arbitraje. Cuando NIOC demandó al estado de Israel, éste no designó a su árbitro de parte lo que evidenció un vacío pues el Reglamento Arbitral solo habilitaba a que la CCI designe al presidente del Tribunal Arbitral y no al árbitro de parte. Si bien la ley israelí preveía que en esos casos el Juez debía designar el árbitro, NIOC no podía acudir a los Tribunales de ese país, pues debido a la revolución de 1979, Irán era considerado un estado enemigo de Israel, por lo que acudió a las Cortes de París, donde la Primera Cámara Civil de la Corte de Casación (Casos 01-13742 y 02-15237) rechazó las impugnaciones del Estado y designó al árbitro del demandado.

Lo anterior fue posible gracias a que en Francia los artículos 1451 y 1454 del Código de Procedimiento Civil francés (modificado el 2011 por el Decreto 2011-48) prevén que, ante los problemas de constitución del tribunal arbitral, se podrá acudir al juez competente. Sin embargo, estimamos que una esta intervención judicial similar no podría ser rechazada en virtud del art. 3 LA que recoge el principio de no interferencia judicial. Eso porque la intervención judicial antes descrita no tuvo como propósito cerrar o perturbar el inicio, trámite o eficacia del arbitraje, sino que buscó abrir las puertas a la vía arbitral.

\subsection{La independencia de los tribunales arbitrales}

El art. 3, num. 2, LA consagra la independencia de los tribunales arbitrales, de modo que no estén sujetos a mandatos externos que menoscaben sus funciones. Se reconoce aquí la usual garantía de independencia judicial en el campo arbitral.

Al respecto, el art. 139, inc. 2 de la Constitución consagra como principio y derecho de la función jurisdiccional "la independencia en el ejercicio de la función jurisdiccional", de modo que "ninguna autoridad puede (...) interferir en el ejercicio de sus funciones". Tales perturbaciones no solo pueden provenir de jueces, sino del legislador que pretendiera alterar de modo inválido la eficacia de los acuerdos o de los procedimientos arbitrales, o de entidades administrativas, e incluso de instituciones arbitrales. Es decir, la garantía de la independencia tiene amplio espectro y puede ser opuesta a cualquier ente o sujeto que pretenda influir o perturbar en el ámbito netamente jurisdiccional, esto es, en la interpretación y aplicación del Derecho, en la valoración del material probatorio y/o en el trámite mismo del procedimiento arbitral.
En efecto, el TC entiende que el principio de independencia impide que "(...) sea posible la injerencia de extraños [otros poderes públicos o sociales, e incluso órganos del mismo ente judicial] a la hora de delimitar e interpretar el sector del ordenamiento jurídico que ha de aplicarse en cada caso" (STC 00023-2003-Al, fd. 29 y STC 0004-2006-Al, fds. 17-18). Eso puede ocurrir, agrega el TC, por ejemplo, ante

(...) el desplazamiento del juzgamiento de un caso o controversia que es de competencia del Poder Judicial [o de un Tribunal Arbitral], hacia otra autoridad de carácter gubernamental, o incluso jurisdiccional, sobre asuntos que, además de ser de su competencia, se encuentran pendientes de ser resueltos ante aquel (STC 4952-2011-AA, fd. 5).

De acuerdo con lo anterior, el principio de independencia de la función jurisdiccional no sólo supone una prohibición hacia terceros de no intromisión, sino que exige medidas positivas de sus titulares (en este caso, de los tribunales arbitrales) para no permitir o rechazar cualquier intento de interferencia o perturbación de cualquiera de sus funciones jurisdiccionales.

Por lo demás, recientemente el voto mayoritario de la STC 0003-2020-Al (fds. 64-77) reconoce la aplicación del principio de independencia judicial a los arbitrajes. Esto con motivo de los reclamos de inconstitucionalidad contra el art. 6, num. 6.4 y la Primera Disposición Complementaria Transitoria del Decreto de Urgencia 014-2020(22). Esta última norma disponía que, en un arbitraje derivado de una negociación colectiva con trabajadores del sector público que pudiera afectar la disponibilidad presupuestaria, el Ministerio de Economía y Finanzas emitirá un Informe Económico Financiero para la eventual revisión y suspensión del convenio colectivo en cuestión y/o del laudo arbitral.

Lo curioso es que el art. 6, num. 6.4, del referido Decreto va más allá al disponer que si el convenio colectivo o el laudo contraviene el Informe Económico, incurre en causal

(22) Cabe aclarar que, de acuerdo con el art. 5 de la Ley Orgánica del TC, se necesitan de cinco votos conformes para que el TC pueda declarar la inconstitucional de una ley. En este caso, hubo cuatro votos a favor para que se declare fundada e inconstitucionales las normas referidas. Sin embargo, los otros tres votos optaron por declarar improcedente la demanda debido a que la Ley 31114 derogó el Decreto de Urgencia 014-2020. Es decir, no hubo desacuerdo con respecto al contenido del voto en mayoría, sólo se consideró que había operado la sustracción de la materia. Por tal motivo, usamos como criterio orientador el voto en mayoría. 
de nulidad y los árbitros son pasibles de acciones civiles, administrativas y penales. El voto en mayoría del TC (fds. 7882) resaltó que lo anterior podría generar una afectación del principio de independencia de los árbitros, al imponérsele la obligación de darle un valor probatorio absoluto a los Informes Económicos (una suerte de prueba tasada). Por eso, se estimó que las normas citadas no eran inconstitucionales si eran interpretadas no como mandatos absolutos, sino que dejaban a los árbitros la libertad para valorar dicho Informes y su adecuación o no con los principios presupuestales.

Una afectación similar al principio de independencia arbitral se aprecia en la modificación incorporada por el Decreto de Urgencia 020-2020 al art. 8, num. 8.2, LA. Tal norma dispone que en los arbitrajes en donde el Estado es parte afectada con una medida cautelar, se exigirá como contracautela una carta fianza bancaria cuyo monto podrá ser definido por el juez o árbitro, pero que en ningún caso deberá ser menor a la garantía de fiel cumplimiento prevista en el contrato. Otra vez, el legislador impone el valor probatorio que se deben asignar a ciertas pruebas, en específico, a las pruebas de un pedido cautelar.

Recuérdese que, de acuerdo con el art. 613 del Código Procesal Civil, la contracautela asegura que el afectado con una cautelar pueda ser resarcido si se generan daños indebidos con la ejecución de aquella. En tal sentido, se dispone que el juez valorará la causa para definir la naturaleza y monto de la contracautela que sea adecuada a cada caso. En cambio, el art. 8, num. 8.2, LA, elimina esa independencia, pues obliga a que los jueces y árbitros no valoren que la contracautelar sea adecuada, sino que le imponen un solo tipo de contracautela posible, e incluso define el monto mínimo que debe tener ésta. Esto lleva a situaciones tan absurdas como obligar a las partes a ofrecer como contracautela cartas fianzas para una medida cautelar de no ejecución de otras cartas fianzas que fueron entregadas para garantizar las prestaciones del contrato. Se trata, sin duda, de una afectación de las garantías del debido proceso, en su modalidad de independencia de los órganos jurisdiccionales.

En resumen, el art. 3, num. 2, LA reconoce la posibilidad de trasladar la garantía de independencia jurisdiccional al campo arbitral, cuyos alcances no solo se limitan a impedir la intromisión judicial, sino cualquier otra que pretenda perturbar la función jurisdiccional que corresponde a los árbitros en la interpretación y/o aplicación del Derecho, la valoración de las pruebas, la decisión y el trámite mismo del procedimiento arbitral.

\subsection{Protección del fuero arbitral por el kompetenz- kompetez}

El art. 3, num. 3, LA consagra el principio kompetenz-kompetez que será materia de un estudio separado (art. 40, num. 1, LA). Basta por ahora resaltar que la finalidad de ese principio es evitar que un Juez cuestione la competencia de un tribunal arbitral para conocer de un caso y así trunque el inicio y trámite del arbitraje, tal como ocurrió en el caso de Exploraciones Algamarca antes desarrollado.

El principio kompetenz-kompetez no resta importancia al control judicial sobre la competencia de los árbitros para decidir un caso. Solo precisa cuándo corresponde ese control. En términos prácticos, Paulsson (2005) explica que:

Los árbitros deben poder decidir las objeciones a su competencia en lugar de verse obligados a detener su trabajo y esperar una determinación judicial. De lo contrario, quien invoca legítimamente un convenio arbitral válido deberá gastar mucho tiempo y dinero en procesos judiciales (...) solo para saber, después de muchos años, que volverá al lugar inicial, aunque luego someterse al tipo de las batallas que las partes convinieron evitar, por lo que comenzará desde el inicio un caso obsoleto o sin recursos. Igualmente, si la recusación competencial era válida, solo un tribunal podría tomar esa decisión, el tribunal arbitral debe ser ese paso innecesario, a pesar de sus cuestionamientos, hasta pasar la posta a un juez.

Así se asegura la eficacia del acuerdo de ir a un arbitraje y se evita cualquier interferencia en su trámite. La eventual decisión del tribunal arbitral que confirma su propia competencia recién debe ser objeto de revisión judicial al final del arbitraje, junto con el Laudo. En virtud del kompetez-kompetenz, ningún ente distinto al designado por las partes para un caso (sea judicial, administrativo o incluso arbitral) podrá, interferir o dirigir el proceso arbitral.

Es ilustrativo el caso Himpurna California Energy Ltd. y otro contra Perusahaan Listruik Negara (PLN), regido por el Reglamento UNCITRAL. Paulsson (2005, pp. 150 y ss.), árbitro del caso, recuerda que después de que PLN fue condenando a pagar una indemnización, otra empresa estatal obtuvo una cautelar que dispuso que ese y otro arbitraje sean suspendidos. Los árbitros consideraron arbitraria esa injerencia y, conforme a sus atribuciones para definir su competencia, decidieron continuar el arbitraje con audiencias en La Haya, sin cambiar del lugar del arbitraje (en Yakarta, Indonesia). Pero las autoridades indonesias interceptaron 


\section{A modo de conclusión}

a las audiencias. El incompleto Tribunal acordó que tenía facultades para continuar y laudar, negándose a ceder su competencia.

\subsection{Algunas experiencias del derecho comparado}

Finalmente, el art. 3, num. 4, LA dispone que además del control judicial en vía de anulación de laudo no cabe otra forma de intervención judicial. Ya vimos que el TC dictó un mandato vinculante para abrir la posibilidad de revisión en vía de amparo para supuestos específicos, asunto que estimamos legítimo en la medida que se trata de intervenciones excepcionales que no desnaturalizan la figura del arbitraje, ni se pueden activar mientras esté siga en curso.

En el derecho comparado, un intento del Poder Ejecutivo para truncar arbitrajes se vio en Société des Grands Travaux de Marseille contra East Pakistan Industrial Development Corporation, administrado por la CCl (Caso 1803). Se demandó a la empresa pública paquistaní por un contrato de construcción de gaseoducto, pero dos años después, el lugar pasó a la República Popular de Bangladés, que por Decreto Presidencial traslado la titularidad a Bangladesh Industrial Development Corporation y ordenó el cese de los arbitrajes, de modo que "ningún laudo o decisión dictada en tales procedimientos tendrá efectos, ni será vinculante o exigible" para el Estado y su empresa nacional. Esa Orden Presidencial fue una respuesta a la decisión del árbitro de reemplazar como demandado a la empresa paquistaní por la empresa bangladesí y su Estado. Luego del Laudo favorable a la empresa francesa, Bangladés inició acciones judiciales y logro que el Tribunal Federal Suizo (lugar del arbitraje) anulara el Laudo por incorporar a terceros ajenos al convenio arbitral.

También hay casos donde es el legislador quien buscar truncar arbitrajes. En Stran Greek Refineries y otro contra Grecia, se dictó un Laudo que ordenaba un pago a favor de la empresa del Sr. Stran por el incumplimiento de obligaciones vinculadas con la construcción de una refinería. Eso motivó una demanda de anulación de laudo del Estado y, ya en la instancia final del proceso, el dictado de una Ley del Parlamento griego que disponía que los contratos celebrados en el período de la dictadura militar quedaban derogados, efecto que se extendió hasta las cláusulas arbitrales pactadas. El Laudo finalmente fue anulado por el Tribunal de Casación griego al considerarse que la referida Ley había generado que los árbitros perdieran jurisdicción para resolver la controversia. Finalmente, el Sr. Stran acudió hasta el TEDH (ver supra nota a pie 2) que extendió protección al solicitante contra Grecia por agraviar sus derechos al debido proceso y a la propiedad, debido a que el Estado había interferido en un proceso judicial e impedido la eficacia de un mandato que reconocía derechos al solicitante.
Como se habrá podido verificar, la articulación entre vía arbitral y judicial encierra mucho mayor complejidad que un simple control judicial posterior de un laudo.

De un lado, el principio de no interferencia en los arbitrajes ordenados por ley y no en la autonomía de voluntad de las partes, debe tender a cierta flexibilización y favorecer, cuando sea razonable, la posibilidad de solicitar tutela judicial frente a un arbitraje que aún no concluye, pero sobre el cual las partes no prestaron consentimiento alguno.

De otro lado, el principio de no interferencia también debe ceder cierto espacio frente a terceros que no prestaron su consentimiento en arbitrajes que, sin embargo, afectan sus derechos. Aunque debe tenerse cuidado en identificar adecuadamente de qué terceros estamos hablando para no tergiversar esta habilitación que hace el TC para que estos sujetos recurran a la vía de amparo para el control judicial de los laudos. De manera similar, cuando el laudo trasciende a los intereses de las partes porque contiene un peligroso poder de control difuso, de inaplicación de normas jurídicas, o de inaplicación de precedentes vinculantes constitucionales, el principio de no interferencia y su fundamento -la autonomía de la voluntad- también deben ceder espacio al control judicial directo mediante procesos de amparo.

En todo caso, con excepción de ciertos supuestos que se dan en los arbitrajes impuestos por ley, el principio de no interferencia logra imponer como regla general que el control judicial de los arbitrajes sea posterior, ya sea en amparo o en anulación de laudo, lo que constituye un gran avance en favor de la eficacia de los arbitrajes.

\section{Referencias bibliográficas}

Allorio, E. (1935). La cosa giudicata rispetto ai terzi. Giuffrè.

Redfern, A. \& Hunter, M. (2016). Redfern and Hunter on international arbitrarion ( $6^{\mathrm{a}}$ ed). Oxford University Press. 
Born, G. (2009). The Principle of Judicial Non-Interference in International Arbitral Proceedings. University of Pennsylvania Journal of International Law, 30(4), 999-1033. https://scholarship.law.upenn. edu/jil/vol30/iss $4 / 22$

Born, Gary B. (2014). International Commercial Arbitration (2 ${ }^{\mathrm{a}}$ ed. Tomo I). Kluwer Law International.

Bustamante, R. (2019). El control difuso en sede arbitral. Forseti. Revista De Derecho, 10, 93-115. https://doi.org/10.21678/forseti. v0i10.1101.

Caivano, R. (2007). Algunos problemas derivados de los arbitrajes con partes o relaciones jurídicas múltiples. Revista Peruana de Arbitraje, (4), 65-120.

Carpi, F. (2007). La eficacia 'ultra partes' de la sentencia civil (Juan Monroy, trad.). Palestra Editores.

Castillo, L. (2006). Comentarios al Código Procesal Constitucional (2a edición. Tomo I). Palestra.

Chiovenda, G. (1954). Instituciones de Derecho Procesal Civil. (E. Gómez, trad.). Revista de Derecho Privado.

Consolo, C. (2012). I terzi e il procedimento arbitrale. Rivista di diritto procesuale, 67(4), 841-873. http://hdl.handle.net/11577/2573805

Cuartero, V. (1997). El recurso de anulación contra el laudo arbitral en el arbitraje comercial internacional. Eurolex.

Cross, R. \& Harris, J. W. (2012). El precedente en el derecho inglés (Angélica Pulido, trad.). Marcial Pons.

Davelouis, L (13 de noviembre de 2014). ¿Cómo la hizo Orellana? I, II y III. La Ley - El ángulo legal de la noticia. http://laley.pe/not/1876/como-la-hizo-orellana-i-/

Duxbury, N. (2008). The nature and authority of precedent. Cambridge University Press.

Fabrini, G. (1964). Contributo alla dottrina dell'intervento adesivo. Giuffrè.

Gaillard, E. \& Banifatemi, Y. (2008). Negative Effect of CompetenceCompetence: The Rule of Priority in Favour of the Arbitrators. En Gaillard \& Domenico (eds.), Enforcement of arbitration agreements and international arbitral awards: The New York Convention in practice (pp. 257-273). Cameron May Ltd.

Goodhart, A. (1930). Determining the Ratio Decidendi of a Case. Yale Law Journal, 40, 161-183. https://doi.org/10.2307/790205

Hanotiau, B. (2005). Complex arbitrations: multiparty, multicontract, multi-issue and class actions. Kluwer Law.

Harris, D.; O'Boyle, M.; Bates, E., Buckley, C. \& Warbrick, C. (2018). Law of the European Convention on Human Rights (5 $5^{\mathrm{a}}$ ed.). Oxford University Press

Liebman, E. T. (1946). Eficacia y autoridad de la sentencia. (Santiago Sentís Melendo, trad.). Ediciones Jurídicas Europa- América.

Lorca, A M. (2008). La anulación de laudo arbitral. Instituto Vasco de Derecho Arbitral.

Luiso, F. (1981). Principio del contraddittorio ed efficacia della sentenza verso terzi. Giuffrè.
Matehus, C.A. (2018). La extensión del convenio arbitral a partes no signatarias. Instituto Vasco de Derecho Procesal.

Morello, A. \& Vallefín, C. (1998). El amparo. Régimen procesal. ( $3^{\mathrm{a}}$ ed.). Platense.

Mori, P. (2016). Buenas y malas. El Tribunal Constitucional y el desarrollo actual del artículo 14 de la Ley peruana de Arbitraje (extensión del convenio arbitral a no signatarios),. En Alfredo Bullard (ed.), Litigio arbitral. El arbitraje desde otra perspectiva (pp. 149-164). Palestra.

Mori, P. \& Galluccio. G. (2012). Arbitraje comercial. Ediciones Legales, lus et Veritas.

Park, W. (2012). Arbitration of international business disputes. ( $2^{\mathrm{a}}$ ed.). Oxford University press.

Paulsson, J (2005). Denial of justice in international law. Cambridge University Press.

Reggiardo, M. \& Cuba, A. (2020). Las medidas antiproceso en el arbitraje peruano. THEMIS Revista De Derecho, 77, 233-252. https://doi. org/10.18800/themis.202001.012

Rodríguez, J. A. (2000). El principio de relatividad de los contratos en el derecho español. Editorial Colex.

Sagüés, N. P. (1995). Derecho Procesal Constitucional. Acción de amparo (4⿳a ed.). Astrea.

Schmitt, C. (1982). Teoría de la Constitución. (Francisco Ayala, trad.). Alianza Editores.

Organización Internacional del Trabajo (1996). Informe $N^{\circ} 302$, del Comité de Libertad Sindical https://www.ilo.org/dyn/normlex/es/f?p=1000:50 002:0::NO:50002:P50002 COMPLAINT_TEXT ID:2903604.

Velásquez, R. (2012). Desenredando el artículo 5.2 del Código Procesal Constitucional ¿Cuándo debe despertar el amparo? En S, Sosa.(coord.), La procedencia en el proceso de Amparo (pp. 41-86). Gaceta Jurídica.

Velásquez, R. (2015a). La subsidiariedad del amparo peruano. Comentarios al precedente Elgo Ríos. Diálogo con la jurisprudencia, 205, 66-76.

Velásquez, R. (2015b). Comentarios a los artículos 45 y 46 del Código Procesal Constitucional: vías previas al amparo y excepciones". En Comentarios al Código Procesal Constitucional (pp. 489-497). Gaceta Jurídica.

Velásquez, R. (2015c). Arbitraje Laboral Potestativo como Final Offer Arbitration. IUS ET VERITAS, 50 398-407. http://revistas.pucp.edu.pe/index.php/ iusetveritas/article/view/14828 
Velásquez, R. (2016). Partes y Terceros en los Contratos y los Arbitrajes (Primera Parte: el principio de relatividad contractual y los terceros). IUS ET VERITAS, 52, 214-226. http://revistas.pucp. edu.pe/index.php/iusetveritas/article/view/16381
Velásquez, R. \& Avendaño, J. L. (2012). El nuevo precedente constitucional sobre Arbitraje. En especial, sobre la revisión judicial solicitada por 'terceros'. Anuario Latinoamericano de Arbitraje, 2, 189-207. (9) 